\title{
PROCEEDINGS
}

\section{Recent developments in pertussis research}

\author{
-based upon papers presented at the European workshop on pertussis held at the National Institute for Biological \\ Standards and Control on 1 December 1989
}

Edited by M. J. CORBEL and K. REDHEAD

Division of Bacteriology, National Institute for Biological Standards and Control, Blanche Lane, South Mimms, Potters Bar, Herts EN6 30 G

This workshop was attended by approximately 100 delegates from Europe, North America and Japan. The main emphasis of the presentations was on the bacterial components involved in the pathogenicity of Bordetella pertussis and their application to the development of new vaccines. New information was presented on the structure and biological activities of pertussis toxin, genetically modified pertussis toxin, adenyl cyclase toxin (cyclolysin) "69-Kda" protein (pertactin) and fimbrial agglutinogens. The results of the recent Swedish clinical trial of acellular pertussis vaccines and studies on experimental vaccines based on synthetic peptides, AroA-deficient mutants of $B$. pertussis and new formulations of acellular vaccines containing additional antigens such as $69-\mathrm{Kda}$ protein were also discussed. The importance of T-lymphocytes and cellmediated immunity to pertussis was indicated by studies in animal models.

ACQUISITION OF IRON BY B. PERTUSSIS GROWN UNDER IRON-LIMITED CONDITIONS IN VITRO

\section{A. R. Gorringe, G. Woods and A. Robinson}

\section{PHLS CAMR, Porton Down, Salisbury SP4 OJG}

Iron is an essential nutrient for bacterial growth but it is largely unavailable in animal tissues, where most is either in intracellular stores or complexed with iron-binding glycoproteins. The ability of $\boldsymbol{B}$. pertussis to colonise and multiply on the mucosal surface of the upper respiratory tract suggests that it has a means of obtaining iron during infection. Ironlimited growth conditions were produced either by the addition of the iron chelator ethylene diamine di-orthohydroxyphenyl acetic acid (EDDA) to defined medium or by removing iron from the medium by passage through a Chelex 100 ion-exchange column.

It was demonstrated that under iron-restricted conditions produced by the addition of EDDA, B. pertussis could obtain iron from iron-saturated human transferrin. Direct contact between $B$. pertussis and transferrin was not required as $B$. pertussis was able to acquire iron from transferrin when they were separated by a dialysis membrane. This indicated that $B$. pertussis produced siderophores that were able to scavenge the iron and pass through the dialysis membrane. Siderophore activity was subsequently detected in culture supernates from iron-restricted cultures of $\boldsymbol{B}$. pertussis, $\boldsymbol{B}$. bronchiseptica and $B$. parapertussis. The siderophores were identified as hydroxamates and were produced by both virulent and avirulent strains of $B$. pertussis.

Sodium dodecyl sulphate-polyacrylamide gel electrophoresis (SDS-PAGE) analysis of Empigen BB-extracts of ironreplete and iron-restricted $B$. pertussis (fig. 1) showed the expression of a $37-\mathrm{Kda}$ iron-regulated protein, the same mol.

Received 20 Dec. 1990; accepted 9 March 1991. wt as the major iron-regulated protein of Neisseria spp. In addition, a 74-Kda iron-regulated protein was observed in outer-membrane fractions of $B$. pertussis (fig. 1). This is the same mol. wt as the Col V-aerobactin receptor of Escherichia coli and the observation that $B$. pertussis produces aerobactintype hydroxamate siderophores may indicate a role for the 74-Kda protein in iron uptake.

These results and the observation of Redhead et al. ${ }^{1}$ that transferrin can bind to the surface of $B$. pertussis suggested that $B$. pertussis may possess a dual mechanism for obtaining iron from iron-binding proteins in vivo, involving the use of hydroxamate siderophores and direct contact with transferrin.

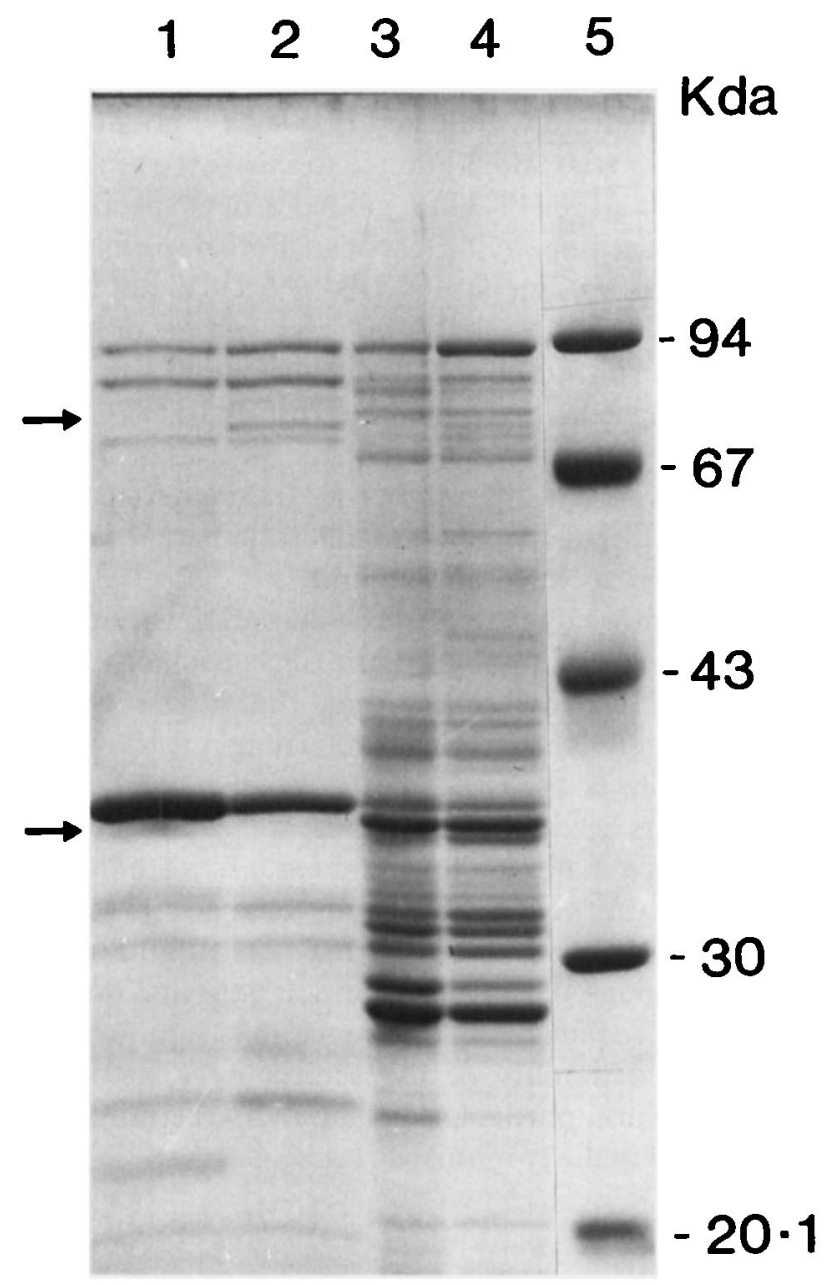

Fig. 1. SDS-PAGE of $B$. pertussis extracts grown in iron-replete and iron-restricted conditions. 1, Outer-membrane preparation, $\mathrm{Fe}^{+} ; 2$, outer-membrane preparation, $\mathrm{Fe}^{-} ; 3$, Empigen $\mathrm{BB}$ extract, $\mathrm{Fe}^{+} ; 4$, Empigen $\mathrm{BB}$ extract, $\mathrm{Fe}^{-} ; \mathbf{5}$, mol. wt markers. 
THE ROLE OF THE DISULPHIDE BOND AND THE CARBOXYTERMINAL HYDROPHOBIC REGION OF THE S1 SUBUNIT IN THE ASSEMBLY AND BIOSYNTHESIS OF PERTUSSIS TOXIN

Rudy Antoine and Camille Locht

Department of Molecular and Cellular Biology, Smith KlineBiologicals, 89 rue de l'Institut, B-13330 Rixensart, Belgium

For the analysis of the structure-function relationship, the assembly in vivo, and the biosynthesis, of pertussis toxin (PT), a B. pertussis expression system was developed. The structural PT gene was first deleted from the $B$. pertussis chromosome. In the resulting $B$. pertussis strain, the PT gene was then introduced on a low-copy-number broad-hostrange plasmid. The amounts of produced and secreted PT in this expression system was of the same order of magnitude as those produced by $B$. pertussis, Tohama I, indicating that the plasmid may be present in more than one copy per cell. Overproduction of PT was not achieved in $B$. pertussis. Expression of mutant PT genes in which the codon for Cys41 was deleted or altered, or in which the carboxy-terminal hydrophobic region was deleted, showed that both the single intra-chain disulphide bond as well as the carboxy-terminal regions of the $\mathrm{S} 1$ subunit are essential for the stable expression, assembly and secretion of the S1 subunit. Furthermore, due to its hydrophobic nature, the deletion of the carboxy-terminal region has a drastic effect on its solubility, suggesting that the S1 subunit interacts with the B oligomer through hydrophobic interaction, possibly via the S5 subunit. On the other hand, the B oligomer is efficiently secreted in the culture medium in the absence of the $\mathrm{S} 1$ subunit. The secreted $B$ oligomer contains $S 2, S 3$ and S4 subunits, as shown by ELISA, and is fully functional with respect to haptoglobin-binding.

\section{CROSS-LINKING OF PERTUSSIS TOXIN SUBUNITS}

Margaret D. Lobban and S. van Heyningen

Department of Biochemistry, University of Edinburgh, Hugh Robson Building, George Square, Edinburgh EH8 9XD

PT is made up of five subunits (S1-S5) distinguished on the basis of their decreasing molecular weights. It has been suggested that their molar ratios within the holotoxin is $1: 1: 1: 2: 1$ respectively. We have investigated this stoichiometry and the spacial arrangement of the toxin subunits by use of reversible cross-linking reagents, two-dimensional gel electrophoresis and Western blotting.

The cross-linking reagents used were dithiobis (succinimidyl propionate; DSP) and disuccinimidyl tartarate (DST). They have molecular spans of $12 \dot{A}$ and $6 \cdot 8 \dot{A}$ respectively. Both reagents cross-link lysine or arginine residues at one part of the protein to the same group at another locus along the length of the molecule. DSP has an internal disulphide bond which can be cleaved by reducing agents and DST can be cleaved with oxidising agents. We hoped to use these cross-linkers to demonstrate which subunits are in close association within the holotoxin.

PT was incubated with reagent, and the products were separated on a first-dimension gradient SDS-polyacrylamide gel. We then hoped to reduce the internal disulphide bond, separating the linked subunits, and run the reduced products on a second-dimension gel. This would establish which subunits are involved in each conjugate. This has proved difficult and has been only partially successful. As an alternative, to confirm the results obtained from twodimensional gels, we have Western blotted with monoclonal antibodies against subunits $\mathrm{S} 1, \mathbf{S} 2$ and $\mathrm{S} 3$.

The results obtained so far confirm the model proposed by Tamura et al. ${ }^{2}$ We have shown that $S 1$ is in close association with both $S 2$ and $S 3$, furthering the evidence for the two dimer model of D1, S2 and S4 and of D2, S3 and S4.
$\mathrm{S} 1$ was also shown to be in close association with $\mathrm{S} 2$ and $\mathrm{S} 3$, suggesting that this subunit may sit in a plane above the Bsubunits, as has been suggested for cholera toxin A subunit.

THE BINDING OF PERTUSSIS TOXIN TO HUMAN T LYMPHOCYTES

\section{R. J. Klapmuts and J. T. Poolman}

National Institute for Public Health and Environmental Protection, (RIVM) PO Box 1, 3720 BA Bilthoven, The Netherlands

In this study we analysed the binding of PT and its subunits to human T-lymphocytes by measuring incorporation of ${ }^{3} \mathrm{H}$ thymidine. Measurement of cell proliferation in freshly isolated human peripheral blood mononuclear cells cultured with PT-subunit dimers, revealed mitogenic activity in the S3-S4 dimer.

The mitogenic activity of PT could be blocked by preincubating the toxin with S3-specific monoclonal antibodies (MAbs) but not with MAbs with specificity for other subunits. Moreover, fluorescent antibody labelled cell sorter (FACS) analysis of CD3-positive human lymphocytes demonstrated that the anti-S3-MAbs, but not the other MAbs inhibited the binding of the toxin molecule by the Tcell membrane. Taken together, these results suggest involvement of S3 in PT-cell interactions. To establish whether the widely used Chinese hamster ovary $(\mathrm{CHO})$ cell assay could be used as a model system for studying PTlymphocyte interactions, we tried to neutralise the clustering effect of PT on these cells with PT-specific MAbs. Only S3specific MAbs showed neutralising capacity, suggesting S3 involvement in binding to $\mathrm{CHO}$-cells. Previously it was demonstrated that $\mathrm{S} 3-4$ but not $\mathrm{S} 2-4$ bound to $\mathrm{CHO}$ cell glycoproteins. The CHO cell saccharide structures involved appeared to be $\mathrm{N}$-linked NeuAc-gal-glcNac groups. Similarity in S3-4 binding by $\mathrm{CHO}$ cells and human T-lymphocytes indicated that these saccharide structures are also involved in the binding of pertussis toxin by T-lymphocytes. The lectin-like properties of PT in T-cell activation were further analysed by inhibition experiments with $\mathrm{CD}_{2}$-specific MAbs, directed against different epitopes on the $\mathrm{CD}_{2}$ molecule. PT stimulation was found to be comparable with phytohaemagglutinin (PHA) stimulation and different from ConA and Staphylococcus aureus enterotoxin B-stimulation. We propose that the target-molecule for PT on human Tcells resembles the target molecule for PHA.

\section{T-CELL IMMUNITY IN PROTECTION AGAINST $B$. PERTUSSIS} INFECTION IN MICE

\section{K. H. G. Mills, K. Redhead and J. T. Watkins \\ National Institute for Biological Standards and Control}

While immunity to $B$. pertussis is considered to involve the production of protective antibodies, $T$ cells may also play a role in controlling or preventing the bacterial infection. We have used the murine aerosol challenge model to examine the nature of the immune response involved in clearance of bacteria from the lungs of infected mice.

In preliminary studies it has been shown that mice which have recovered from previous aerosol infection with $B$. pertussis, when challenged, cleared the bacteria from the lungs very rapidly ( $2-5$ days). In contrast, following infection of control non-immune mice, the bacteria multiplied in the lungs over the first 8-10 days and then slowly decreased in number over the next 12-20 days. Mice immunised with the whole-cell vaccine (formalin-treated $B$. pertussis) and challenged with live $B$. pertussis cleared the bacteria much more slowly than convalescent mice. This suggests that natural immunity generated by infection is more efficient at controlling re-infection than that generated by vaccination. 
We examined the role of immune spleen cells in protective immunity by adoptive transfer into immunosuppressed, sublethally irradiated recipient mice. Recipient mice, given, by injection, one spleen equivalent of immune cells derived from a convalescent donor 6 weeks after infection, were capable of clearing the bacteria within 15 days of challenge. In contrast, mice given spleen cells from control non-immune mice and challenged with $B$. pertussis showed the same pattern of increased bacteria numbers followed by a slow decrease, as seen following infection of non-immune nonirradiated mice. In an attempt to examine the role of distinct spleen-cell populations involved in bacterial clearance we depleted $\mathrm{T}$ or $\mathrm{B}$ cells in vitro with anti-Thy-1 or anti-mouse IgG and $M$ and complement respectively. Transfer of Tcell-depleted spleen cells into sublethally irradiated recipients, followed by aerosol challenge, resulted in significantly reduced clearance compared with transfer of unseparated immune spleen cells and approached that observed with non-immune cells. Depletion of B cells from the immune spleen cells also resulted in some slowing in the rate of clearance, but the response was closer to that of the total immune spleen cells than that of the T-depleted group. These findings indicate a role for $T$ cells in immune protection against pertussis, but do not rule out the possibility that the effect is mediated indirectly, through the helper function of $\mathrm{CD}^{+} \mathrm{T}$ cells on the production of antibody by B cells. Further experiments with CD4- or CD8-depleted subpopulations of $\mathrm{T}$ cells should help to clarify the mechanism.

T-cell lines were established from the spleens of $B$. pertussis-infected mice by repeated antigen stimulation with killed $B$. pertussis. The antigen specificity of the T-cell lines revealed that, while they recognised the whole bacteria, they failed to respond to, or responded only weakly to, purified filamentous haemagglutinin (FHA), PT or agglutinogens (AGG) 2 and 3. These findings indicate that the T-cell lines may include specificities mainly directed against other $\boldsymbol{B}$. pertussis proteins or may only "see" antigen when presented on the whole bacteria.

RELATIONSHIP BETWEEN MOUSE-PROTECTIVE AND TOXINNEUTRALISING ACTIVITIES OF ANTI-PERTUSSIS TOXIN MONOCLONAL ANTIBODIES

\section{Hiroko Sato and Y. Sato*}

Department of Applied Immunology and *Department of Bacteriology, National Institute of Health, Tokyo, Japan

In Japan, the less reactogenic but efficacious acellular pertussis vaccine has been in use since 1981 instead of the whole-cell vaccine. After introduction of the new acellular pertussis vaccine, which consists mainly of formalinised PT and filamentous haemagglutinin (FHA), the vaccine acceptance rates increased to high levels and cases of pertussis decreased rapidly. Several factors relevant to this vaccine could be improved, including the assay methods for safety and protective potency used in quality control.

Evidence that PT is the most important protective antigen in the acellular pertussis vaccine has been demonstrated not only by mouse-protection experiments but also by experience of the general vaccination programmes in Japan and the results of trials with Japanese vaccines in Sweden. PT antigen that retains protective immunogenicity without undesirable side effects should be used to develop improved pertussis vaccines. Anti-PT antibody produced by vaccination should have protective activity against pertussis infection and or disease. Several questions should be addressed. How is the protectivity of the antibody determined? PT has a complicated hexameric structure with five subunits designated S1-S5, and many different biological activities which may relate to various adverse reactions to the vaccine; which antibody(ies) against which epitope(s) exert immunoprotectivity? To prevent the disease, which biological activity(ies) of PT must be or need not be neutralised with the antibodies produced by pertussis vaccination? These fundamental questions should be answered if the present pertussis vaccines are to be improved. To answer these questions, we have been studying the relationship between mouse-protective activity and toxinneutralising activity of the antibodies. We used 20 anti-PT monoclonal antibodies (MAbs) and two pertussis infection systems in mice - aerosol challenge and intra-cerebral (i.c.) challenge systems - as experimental models in this study.

Hybridoma-producing anti-PT MAbs were developed by fusion of SP2/0 myeloma cells and spleen cells of BALB/c mice immunised with PT antigens. ${ }^{4,5}$ From these, 20 MAbs were selected for analysis of PT-neutralisation and mouseprotection relationships, and IgG purified from the ascites fluid by HPLC with a preparative hydroxylapatite column (Tonen) as described by Sato et al. ${ }^{5}$ All MAbs except 1B7 which was $\operatorname{IgG} 2 \mathrm{a}$, were of the IgG1 subclass.

Mouse-protection tests were performed as reported previously. ${ }^{4,6}$ For the aerosol challenge experiment, 7-day-old mice (ddy) were immunised passively by intraperitoneal (i.p.) injection of $20 \mu \mathrm{g}$ of MAb $2 \mathrm{~h}$ before challenge with $B$. pertussis, strain 18323. Body weight, white blood cell (WBC) count and survival rate were determined every week for 5 weeks. In the i.c. challenge experiment, 6-week-old female ddy mice were immunised by i.p. injection of $40 \mu \mathrm{g}$ of MAb $2 \mathrm{~h}$ before challenge with the organisms, and the survival rate was determined over 2 weeks.

Toxin-neutralising activities were assayed by methods described previously. ${ }^{5}$ For assay of neutralisation of ADPribosylase (ADPR), $2 \mu \mathrm{g}$ of PT were pre-incubated with $20 \mu \mathrm{g}$ of the MAb and residual ADPR activity was estimated by measurement of the incorporation of ${ }^{32} \mathrm{P}$-ADP-ribose into the CHO-cell membrane protein and the percentage inhibition of ${ }^{32} \mathrm{P}$-incorporation then calculated. AntiChinese hamster ovary (CHO) cell-clustering (CC) activity was calculated from the dose of MAb that neutralised the clustering of $\mathrm{CHO}$ cells with $0.3 \mathrm{ng}$ of PT. Anti-histaminesensitising (anti-HS) activity of the MAb was assayed by determining the survival rate of mice challenged with histamine 3 days after intravenous (i.v.) injection of a mixture of $0.2 \mu \mathrm{g}$ of PT and $10 \mu \mathrm{g}$ of the MAb. Leucocytosispromoting (LP) activity was determined from the WBC counts of mice 3 days after i.v. injection of a mixture of $0 \cdot 1 \mu \mathrm{g}$ of PT and $20 \mu \mathrm{g}$ of the MAb. Neutralisation of LP activity was estimated from the decreasing WBC counts of mice given PT with the MAb compared with the increasing WBC counts without MAb.

Antigen-binding specificity of 20 MAbs was determined by ELISA and immunoblotting. Ten MAbs were anti-SI (I1B7, 3F10, E1E, E2E, 1D7, 3F11, 4D10, 8G4, 10D6 and 11D9), one was anti-S2 (9G8) and recognised an S2-specific region, two were anti-S3 (7E10 and 7G11) and recognised S3-specific regions, four were anti-S23 (11E6, G9A, 10B5 and $10 \mathrm{C} 9$ ) and recognised mainly homologous regions between $\mathrm{S} 2$ and $\mathrm{S} 3$, and three were anti-S4 $(1 \mathrm{H} 2,6 \mathrm{G} 8$ and 9F3). Fig. 2 shows the immuno-precipitating bands produced by the MAbs and one anti-PT polyclonal antibody (PAb) designated M6 with subunits of PT separated by SDSPAGE without reducing reagent. Fig. 3 presents a schematic grouping of the MAbs based on the results of a competitive ELISA.

Mouse-protective activity of the MAbs in an aerosol challenge system was examined. Of the anti-S1 MAbs, 1B7, 1D7, 3F11, 8G4 and 10D6 and 11E6, 10B5 and 10C9 of the anti-S23 MAbs caused good body-weight gain in the mice, less leucocytosis and high survival rates, all parallel (table I). Most antibodies that gave a higher survival rate permitted development of higher levels of acquired immunity against PT, FHA and agglutinogens in response to the challenge 


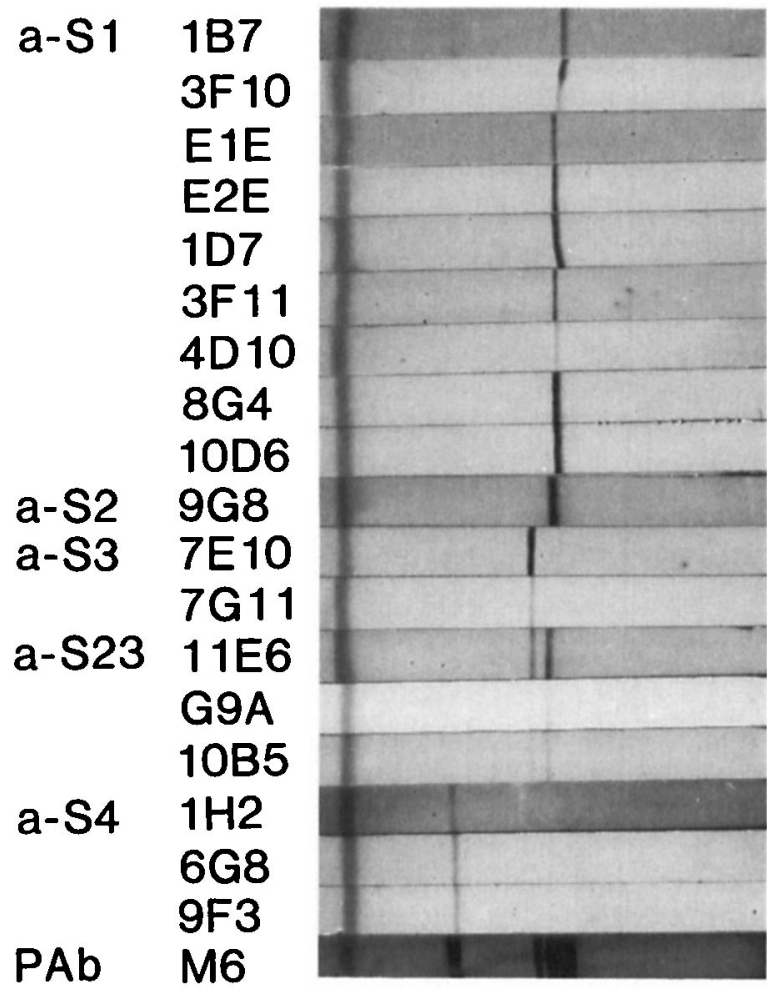

Fig. 2. Immunoblots of MAbs and PAbs, with PT subunits separated by SDS-PAGE.
Table I. Mouse-protective activity of MAbs against aerosol challenge with $B$. pertussis

\begin{tabular}{|c|c|c|c|c|}
\hline & MAb & $\begin{array}{l}\text { Body weight* } \\
\text { (g) }\end{array}$ & $\mathrm{WBC} / \mu \mathrm{l}^{*}$ & $\begin{array}{c}\text { Survival* } \\
(\%)\end{array}$ \\
\hline \multirow[t]{10}{*}{ Anti-S1 } & $1 \mathrm{~B} 7$ & $12 \cdot 6$ & 19000 & 100 \\
\hline & $3 F 10$ & 6.4 & 139000 & 30 \\
\hline & E1E & $8 \cdot 1$ & 59000 & 66 \\
\hline & E2E & $6 \cdot 7$ & 116000 & 50 \\
\hline & 1D7 & $13 \cdot 1$ & 23000 & 90 \\
\hline & $3 F 11$ & $9 \cdot 8$ & 35000 & 90 \\
\hline & $4 \mathrm{D} 10$ & $5 \cdot 6$ & 188000 & 20 \\
\hline & $8 \mathrm{G} 4$ & $9 \cdot 4$ & 40000 & 90 \\
\hline & 10D6 & $12 \cdot 1$ & 22000 & 100 \\
\hline & 11D9 & 6.0 & 159000 & 20 \\
\hline Anti-S2 & $9 \mathrm{G} 8$ & 10.0 & 48000 & 87 \\
\hline \multirow[t]{2}{*}{ Anti-S3 } & $7 \mathrm{E} 10$ & 6.7 & 93000 & 55 \\
\hline & $7 \mathrm{G} 11$ & $9 \cdot 7$ & 57000 & 90 \\
\hline \multirow[t]{4}{*}{ Anti-S23 } & $11 \mathrm{E} 6$ & $10 \cdot 0$ & 27000 & 100 \\
\hline & G9A & $6 \cdot 8$ & 112000 & 78 \\
\hline & 10B5 & $8 \cdot 4$ & 38000 & 100 \\
\hline & $10 C 9$ & $10 \cdot 4$ & 31000 & 100 \\
\hline \multirow[t]{3}{*}{ Anti-S4 } & $1 \mathrm{H} 2$ & 5.9 & 136000 & 20 \\
\hline & $6 \mathrm{G} 8$ & $7 \cdot 4$ & 100000 & 66 \\
\hline & $9 \mathrm{~F} 3$ & 5.9 & 144000 & 30 \\
\hline PAb & M6 & $11 \cdot 5$ & 27000 & 90 \\
\hline \multicolumn{2}{|l|}{ PBS } & $5 \cdot 6$ & 160000 & 20 \\
\hline \multicolumn{2}{|c|}{ Untreated control } & $15 \cdot 6$ & 16000 & 100 \\
\hline
\end{tabular}

*Measurements were made 3 weeks after challenge. PBS, phosphatebuffered saline (control).

S1

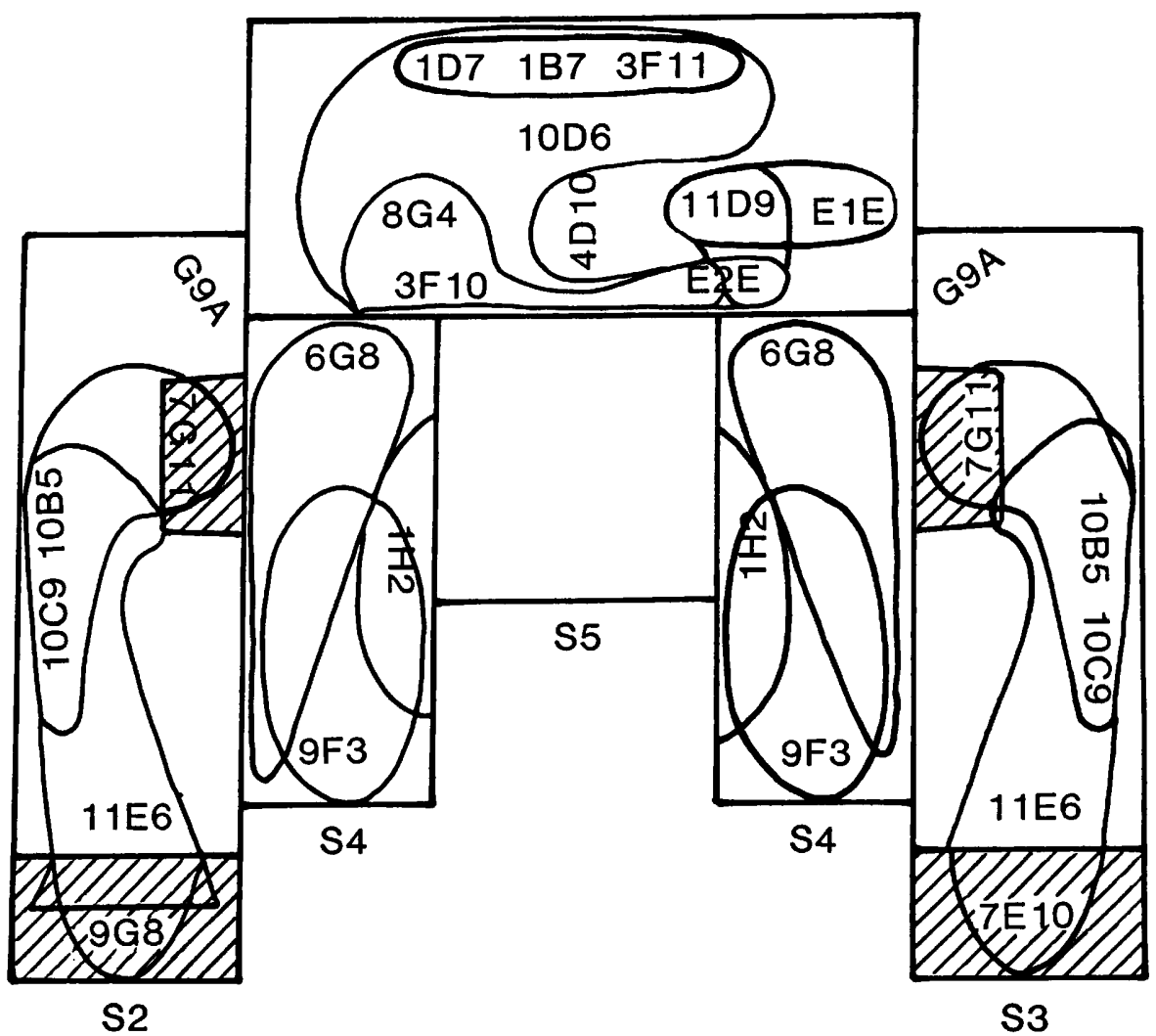

Fig. 3. Schematic grouping of MAbs according to their activity in a competitive ELISA. 
Table II. Comparison of mouse-protective activity of antiPT MAbs in an aerosol infection system with protection against i.c. challenge and PT-neutralisation activities

\begin{tabular}{|c|c|c|c|c|c|c|}
\hline \multirow{3}{*}{ MAb } & \multirow{2}{*}{\multicolumn{2}{|c|}{$\begin{array}{c}\text { Protection } \\
\text { against infection } \\
\text { by }\end{array}$}} & \multicolumn{4}{|c|}{ Neutralisation of } \\
\hline & & & \multirow[b]{2}{*}{ ADPR } & \multirow[b]{2}{*}{$\mathrm{CC}$} & \multirow[b]{2}{*}{ HS } & \multirow[b]{2}{*}{ LP } \\
\hline & aerosol & $\begin{array}{c}\text { i.c. } \\
\text { injection }\end{array}$ & & & & \\
\hline Anti-S1 1B7 & ++ & ++ & ++ & ++ & + & $+t$ \\
\hline 10D6 & ++ & ++ & ++ & - & - & ++ \\
\hline 1D7 & ++ & ++ & + & + & + & ++ \\
\hline $3 F 11$ & ++ & + & ++ & + & - & + \\
\hline $8 \mathrm{G} 4$ & ++ & - & ++ & - & - & ++ \\
\hline Anti-S23 11E6 & ++ & - & + & ++ & + & ++ \\
\hline 10B5 & ++ & - & + & ++ & + & ++ \\
\hline $10 \mathrm{C} 9$ & ++ & + & + & ++ & + & ++ \\
\hline Anti-S1 E1E & + & - & ++ & - & ++ & + \\
\hline Anti-S2 9G8 & + & + & - & ++ & - & + \\
\hline Anti-S3 7E10 & + & - & - & ++ & ++ & ++ \\
\hline 7G11 & + & - & - & ++ & ++ & + \\
\hline Anti-S23 G9A & + & - & - & ++ & - & + \\
\hline Anti-S4 6G8 & + & - & + & + & + & - \\
\hline Anti-S1 3F10 & - & - & ++ & - & - & - \\
\hline E2E & - & - & ++ & - & - & + \\
\hline $4 \mathrm{D} 10$ & - & - & ++ & - & - & - \\
\hline 11D9 & - & - & ++ & - & + & - \\
\hline Anti-S4 1H2 & - & - & - & - & - & - \\
\hline 9F3 & - & - & - & - & - & + \\
\hline
\end{tabular}

,+++ and $-:$ Strong, weak and no protection or neutralisation.

strain, 18323, in the survivors at 5 weeks after aerosol challenge as reported previously. ${ }^{4}$ In table II, the mouseprotective activities and neutralising activities against ADPR, CC, HS and LP activities of PT are summarised. The protection against i.c. challenge seems to depend mainly on anti-S1 antibodies; anti-S2 and -S3 antibodies gave little or no resistance in spite of their high protectivity in the aerosol challenge system. Every anti-S1 MAb inhibited ADPR activity of PT in vitro although four of them did not show any inhibition against either bacterial challenge or the other PT activities. CC activity was inhibited more strongly with antibodies directed against $\mathbf{S} 2$ and $\mathbf{S} 3$ than against $\mathbf{S 1}$. Strong neutralisation of HS activity was not demonstrated with any MAb. The highest inhibition $(++$ in table II) of HS was $33 \%$ in these conditions, although inhibition of the other PT activities and of the bacterial challenges were 90 $100 \%$. LP activity was inhibited by various MAbs. Although there were some exceptions, LP-inhibiting activity of the MAbs by this estimation closely followed the mouseprotection activity in the aerosol challenge system.

These results indicate that greater neutralising activity of the antibody against ADPR, CC or HS activity does not guarantee higher protectivity. Anti-LP activity seems to parallel most closely the mouse protectivity. Even in neutralisation of CC, HS or LP activity, which require whole molecules of PT, the neutralising activities of each MAb were not parallel under the assay conditions. However, toxin-neutralising activity of the antibody is influenced not only by its recognition site on the toxin but also by many other conditions such as affinity or avidity of the antibody to the toxin, test doses or concentrations of the toxin, and toxin-anti-toxin reaction systems. Also, the neutralising activity may vary with calculation methods or with the manner of presentation of results such as percentage inhibition, $\mathrm{ED}^{50}$ and $\mathrm{ED}^{100}$. Even in assays of the anti-LP activity, depending on the estimation method, the ED ${ }^{50}$ values of the MAbs were not necessarily parallel with mouseprotection activity. It is obviously very difficult to predict the protectivity of the antibody from the neutralising activity against just one PT activity but it may not be impossible if the experiment is performed, and the results analysed, cautiously. Competition ELISA with protective $\mathrm{MAb}(\mathrm{s})$ could also be useful to predict the protectivity of the immune sera.

This work was supported by the Ministry of Education, Science and Culture Grant-in-Aid for General Scientific Research.

\section{RECOGNITION OF PERTUSSIS TOXIN BY ANTIBODIES TO SYNTHETIC PEPTIDES}

R. N. Seabrook, A. Robinson, L. Irons and L. A. E Ashworth

\section{PHLS, CAMR}

Eight peptides derived from the amino-acid sequence of PT subunits S1, S2, S3 and S4 were chemically synthesised and coupled to carrier proteins-keyhole limpet haemocyanin, tetanus toxoid or bovine serum albumin (BSA) - for immunisation of mice and rabbits. Seven peptides induced anti-peptide antibodies which bound to homologous peptidecoated ELISA plates and to SDS-denatured PT in Western blots. All of these anti-peptide antibodies, except for those raised against peptide 10 (S1 100-117), reacted with PTcoated ELISA plates, but only antibodies to peptide 9 (S1 237-255) bound to PT captured on to the ELISA plate by the glycoprotein ligand fetuin. Similar results were obtained when ELISA plates were coated with purified anti-peptide IgG; only anti-9 antibodies were able to capture PT from solution. However, anti-protein activity was obtained in the fetuin capture assay for antibodies to peptides 8,11, 13,14 and 15 when PT had been reduced by $250 \mathrm{mM}$ dithiothreitol; antibodies to peptide 9 and anti-protein MAbs did not recognise this modified form of PT. This indicates that the conformation imposed on PT by disulphide bonds is important for anti-protein antibodies and is difficult for short linear peptides to mimic antigenically.

These results demonstrate that antibodies to peptides 8 (S1 35-52), 11 (S2 191-209), 13 (S2 36-53), 14 (153-171) and 15 (S3 94-115) do not recognise native PT. Consistent with this finding, none of the responses (including anti-peptide 9) neutralised PT-induced lymphocytosis, $\mathrm{CHO}$ cell clumping or in-vitro enzyme activity.

PROTECTIVE IMMUNOGENICITY OF TWO SYNTHETIC PEPTIDES SELECTED FROM THE AMINO-ACID SEQUENCE OF B. PERTUSSIS TOXIN SUBUNIT $S 1$

P. Askelör, K. Rodmalm, G. Wrangsell, U. Larsson, S. B. Svenson, J. L. Cowell*, A. Unden $\dagger$ and T. Bartfai†

The National Bacteriological Laboratory, S-105 21 Stockholm, *Praxis Biologics, Inc., Rochester, New York 14623-1493, USA, and +Department of Biochemistry, Arrhenius Laboratory, University of Stockholm, 10691 Stockholm, Sweden

Two peptides, corresponding to amino acids 1-17 and $170-186$ of the amino-acid sequence of PT subunit $\mathrm{S} 1$, were synthesised and coupled to the diphtheria toxin crossreactive mutant protein CRM 197 (or BSA) and evaluated for immunogenicity and protective capacity against challenge with $\mathrm{PT}$ in vivo. The peptide-CRM conjugates induced high antibody titres against native PT in mice (BALB/c, C57/Black, and outbred NMRI) as measured by ELISA (fig. 4). The CRM (or BSA) conjugates of peptides 1-17 and 170-186 fully protected NMRI mice from PT-induced 


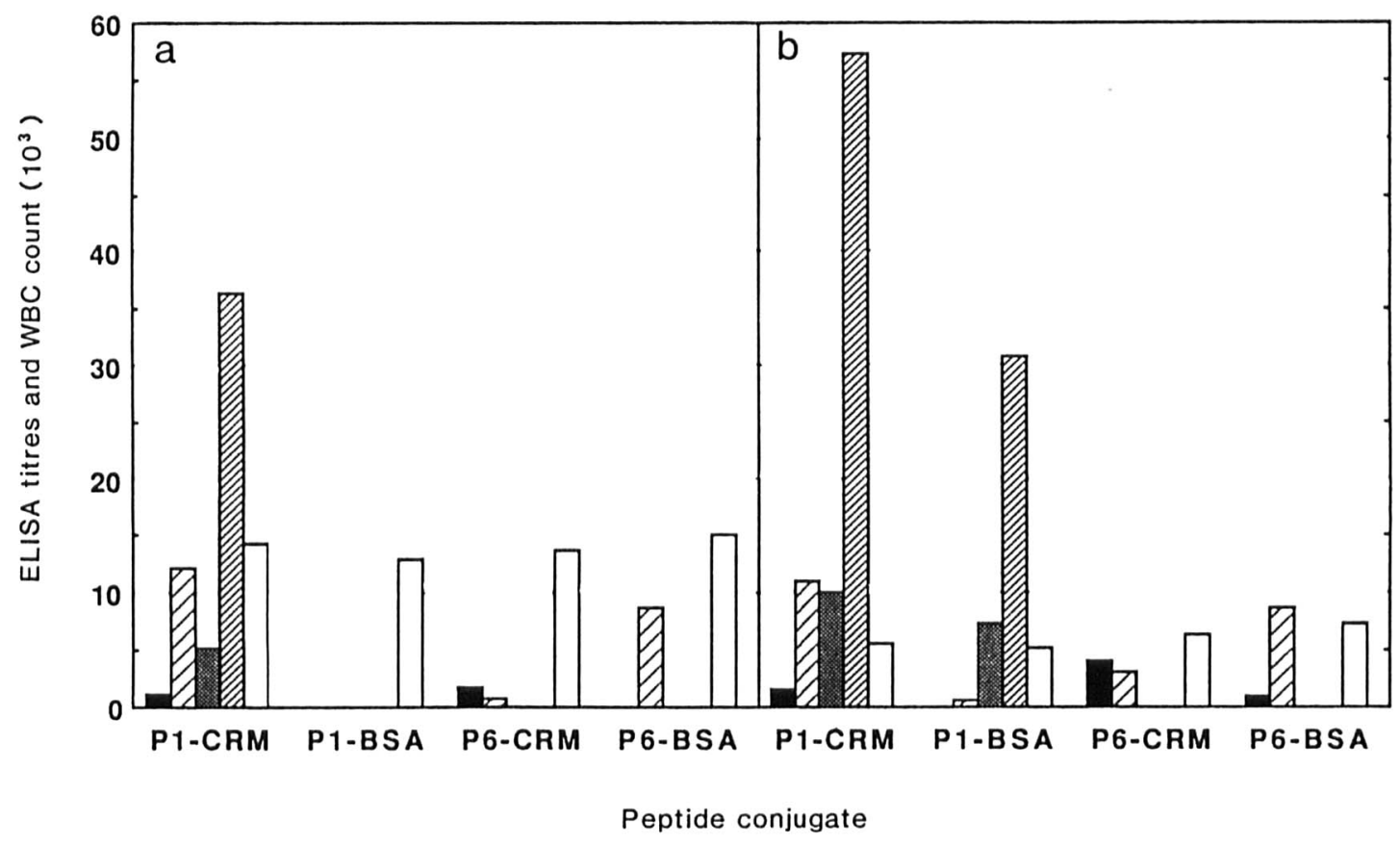

Fig. 4. WBC count $(\square)$ and ELISA titres against toxin $(\square, \mathbb{Z})$ and peptide (圆, 的) in (a) C57/Black and (b) NMRI mice after immunisation $(\square, \mathbb{Q})$ and after challenge $(\mathbb{Z}, \mathbb{Z})$.

leucocytosis after challenge with $0 \cdot 5 \mu \mathrm{g}$ of PT (figs. 5 and 6). The mice that were given peptide $1-17$ conjugates exhibited a strong booster response against both PT and peptide after challenge with PT. A booster response against PT was also noted for mice immunised with peptide 170-186 conjugates. Antibodies against peptide $170-186$ could not be evaluated by ELISA because conjugates of this peptide mimic the immunoglobulin-binding properties of PT. They also cause clustering of $\mathrm{CHO}$ cells. Rabbit antiserum to the peptide
1-17-CRM conjugate was highly efficient in inhibiting the ADP-ribosylating activity of PT but did not neutralise the clustering effect of PT on CHO cells. In contrast, the rabbit antiserum raised against the peptide 170-186-CRM conjugate neutralised the clustering effect of PT on CHO cells but did not inhibit the enzymatic activity of PT. The CRMconjugates of these two peptides constitute the first synthetic pertussis vaccine candidate with the ability to provide a chemically well defined, safe and efficient pertussis vaccine. a

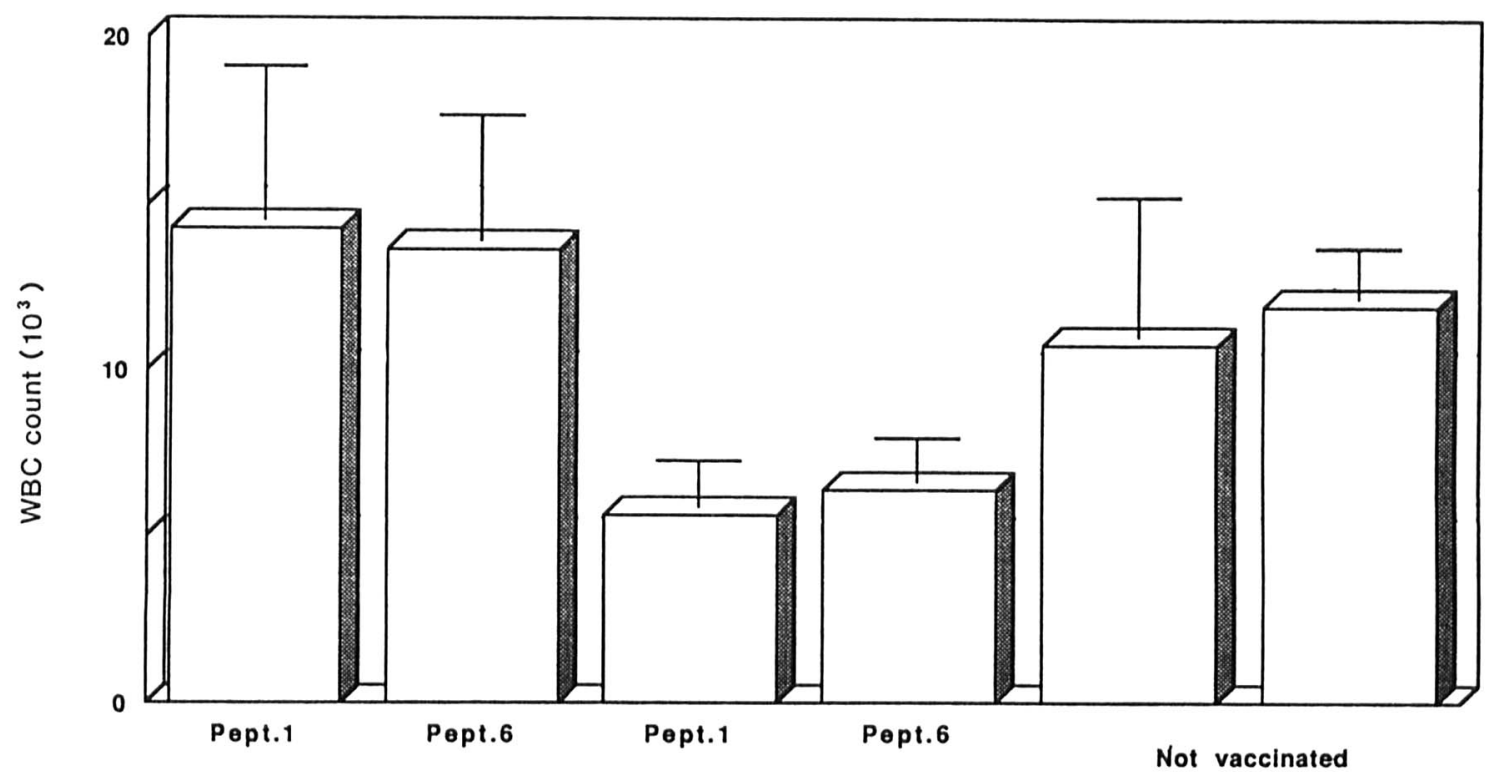

Fig. 5. Leucocytosis after challenge of (a) C57/Black and (b) NMRI mice vaccinated with peptide 1- or peptide 6-CRM (C-Cys) conjugates $(\mathrm{bar}=\mathrm{SEM})$ 
a

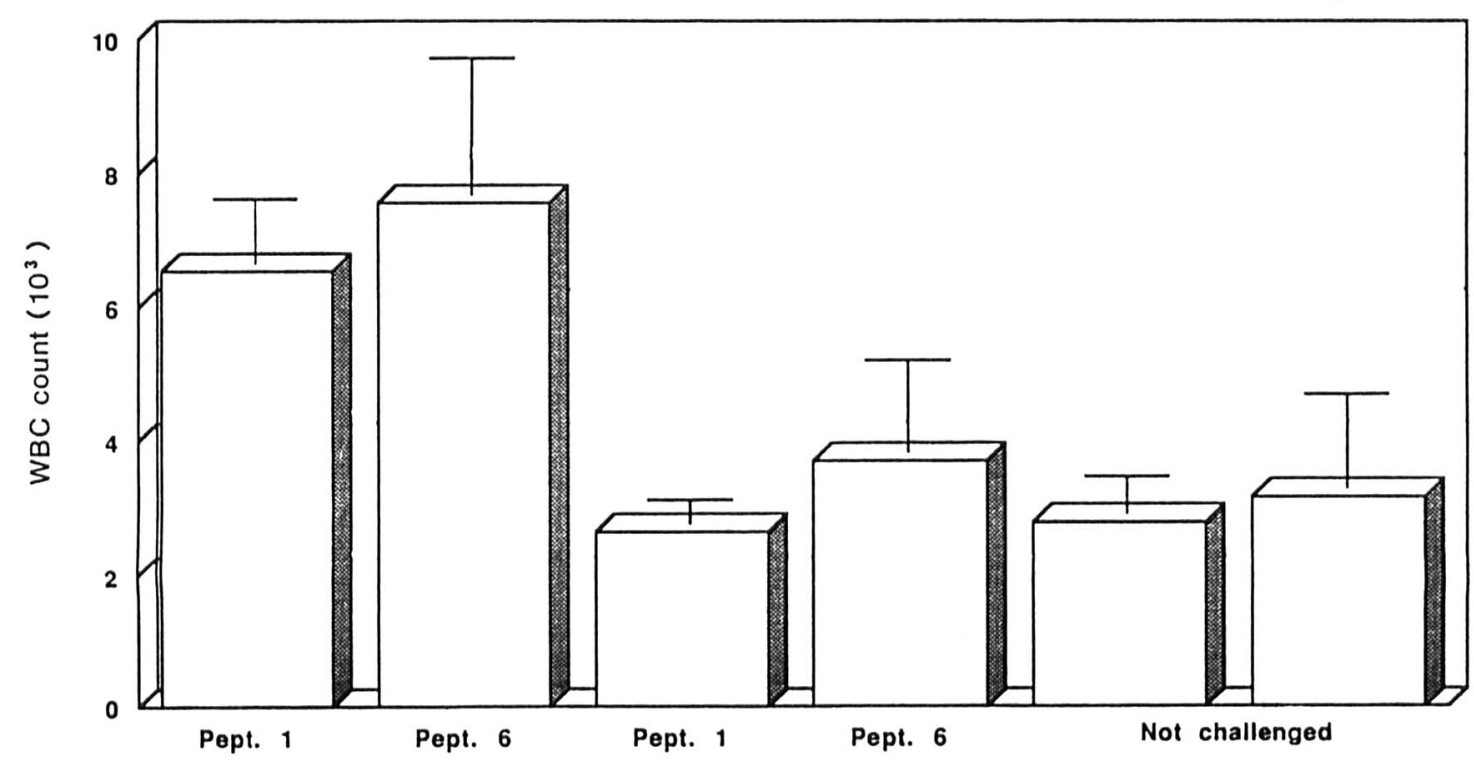

Fig. 6. Leucocytosis after PT challenge of (a) C57/Black and (b) NMRI mice vaccinated with peptide 1- or 6-BSA (C-Cys) conjugates. (For comparison with fig. 4 the values should be multiplied by two.)

PHARMACOLOGICAL ASSAY OF PERTUSSIS TOXIN BASED UPON CLINICALLY RELEVANT PARAMETERS

\section{J. de Wildt}

Laboratory for Pharmacology, National Institute of Public Health and Environmental Protection, The Netherlands

It is well known that pertussis vaccines demonstrate various biological effects. The biologically active components, in particular PT, may provoke adverse reactions in vaccine recipients. Therefore, the possible toxicity of vaccines demands a cautious policy in the production and control of classical and newly developed vaccines. Especially stringent requirements for the quality of in-process and final product control are needed. Recent work in the field of pertussis research at this Institute has been directed towards the elucidation of the cause of cardiovascular or autonomicreceptor side-effects of pertussis vaccines (e.g., shock). Here, we address the control aspects of pertussis vaccines. Present safety tests for pertussis vaccines are inadequate and a PTspecific, sensitive, biologically and clinically relevant safety test is needed. The experimental data obtained from the cardiovascular pharmacological studies indicated a pharmacological method as a reliable quantitative detection method for PT. In various species it was demonstrated that pertussis vaccines caused a long-lasting (at least 28 days) blockade of vascular $\beta$-adrenergic and cardiac cholinergic receptors as well as hypotension and tachycardia. These effects could be attributed completely to the PT component of the vaccines. In a first series of experiments, it was shown that pre-treatment of rats with acellular Takeda-type vaccines (containing detoxified PT), in comparison with classical whole-cell vaccines, did not produce impairment of the cardiovascular autonomic responsiveness and hypotension. In a second series of experiments, the cardiovascular and autonomic effects, after pre-treatment of rats with six different Tn-5 insertion mutant strains of $B$. pertussis (given by $\mathrm{Dr} A$. Weiss), were investigated. These mutant strains were used to evaluate the pharmacological method as a reliable detection method for PT in vaccines. A phenotypic characterisation by Weiss showed that some of the mutant strains were deficient in PT. In a blind study it was possible to detect both qualitatively and quantitatively the presence of biologically active PT by measuring the effects upon the cardiovascular and autonomic system of the rat. A third series of experiments was done in the rat to characterise and quantify the proposed international reference preparation for the quality control of pertussis vaccines-JNIH-5. For this preparation, a dose-dependent relationship (100$1250 \mathrm{ng}$ ) in respect of the hypotensive, the vascular $\beta$ adrenergic antagonising and the anticholinergic effects could be demonstrated. Thus, vaccines to be tested for biologically active PT can now be expressed as JNIH- 5 equivalents by interpolation on a regression line of the JNIH-5 doseresponse curves.

In conclusion, these results demonstrated the cardiovascular method to be a sensitive and reliable method for the detection of biologically active PT. The advantages of this method include the ability to monitor effects upon three independent parameters (blood pressure, $\beta$ - and cholinergic responsiveness) in one relatively simple rat model. Furthermore, the method has clinical relevance with respect to adverse reactions such as shock. Although the predictive value of this test like others, is uncertain, the haemodynamic and autonomic disturbances caused by PT in animals may have a greater relevance than the classical toxicity tests. It would be worth evaluating this pharmacological method, with JNIH-5 as reference compound, internationally at different laboratories in comparison with classical methods.

\section{GENETICALLY ENGINEERED PERTUSSIS TOXIN SUITABLE FOR VACCINE DEVELOPMENT}

\section{R. Rappuoli, L. Nencioni, A. Podda and M. G. Pizza Sclavo Research Center, Via Fiorentina I, Siena, Italy}

Many efforts have been made to develop a safe and immunogenic acellular vaccine against whooping cough containing PT, a major virulence factor of $B$. pertussis. PT is a protein of $105 \mathrm{Kda}$ composed of five subunits designated, according to mol. wt, S1-S5. Subunits S2-S5 form the Boligomer moiety which is capable of binding to glycoproteins on the surface of eukaryotic cells and acts as carrier for the internalisation of the $\mathrm{S} 1$ subunit (A-protomer) into the cells. The A-protomer is responsible for multiple toxic activities 
of PT because of its capacity to ADP-ribosylate a family of GTP-binding proteins involved in receptor-mediated signal transduction.

Unfortunately, all the chemical toxoiding methods used to detoxify PT give rise to products with reduced immunogenicity and, in some cases, with residual holotoxin activity which has been associated with the side-effects of the presently used cellular pertussis vaccine. ${ }^{7}$ To achieve a more complete and stable detoxification we followed a different approach, consisting of the genetic manipulation of PT. To do this, after the cloning and sequencing of the pertussis toxin genes, ${ }^{8}$ the codons for those key amino acids within the enzymatically active $S 1$ subunit which are essential for the expression of ADP-ribosyltransferase activity were replaced in the chromosome of $B$. pertussis. ${ }^{9}$ The resulting recombinant strains of $B$. pertussis produced PT mutant strains containing one or more amino-acid substitutions, which showed reduced or undetectable toxicity and raised protective immunity in animal models. ${ }^{10}$

We summarise here the physico-chemical, biological and immunological properties of the toxin from the double mutant strain, PT-9K/129G, that showed, in SDS-PAGE, the same five bands obtained with wild-type PT. When tested in competition experiments, it was recognised by MAbs and polyclonal antibodies to PT as well as by human $T$ cell clones specific for immunodominant $T$ cell epitopes of S1 subunit. ${ }^{10,11}$

Table III. Some in-vivo and in-vitro biological activities of PT-9K/129G and purified native PT

\begin{tabular}{lcc}
\hline \multicolumn{1}{c}{ Biological activity } & PT & $9 \mathrm{~K} / 129 \mathrm{G}$ \\
\hline Histamine-sensitisation $(\mu \mathrm{g} /$ mouse $)$ & $0 \cdot 1-0 \cdot 5$ & $>50$ \\
Leucocytosis stimulation $(\mu \mathrm{g} /$ mouse $)$ & 0.02 & $>50$ \\
Anaphylaxis potentiation $(\mu \mathrm{g} /$ mouse $)$ & 0.04 & $>7 \cdot 5$ \\
Enhanced insulin secretion $(\mu \mathrm{g} /$ mouse $)$ & $<1$ & $>25$ \\
CHO clustered growth $(\mathrm{ng} / \mathrm{ml})$ & $0 \cdot 005$ & $>5000$ \\
$\begin{array}{l}\text { ADP ribosylation }(\mu \mathrm{g}) \\
\text { Mitogenicity for human }\end{array}$ & $0 \cdot 001$ & $>20$ \\
$\begin{array}{l}\text { lymphocytes }(\mu \mathrm{g} / \mathrm{ml}) \\
\text { Agglutination of chicken erythro- } \\
\text { cytes }(\mu \mathrm{g} / \text { well })\end{array}$ & $0 \cdot 1-0 \cdot 3$ & $0 \cdot 1-0.3$ \\
In-vivo acute toxicity $(\mu \mathrm{g} / \mathrm{kg})$ & $0 \cdot 1$ & $0 \cdot 1$ \\
\hline
\end{tabular}

ND, not determined.

As summarised in table III, when tested for acute toxicity in rats and mice PT-9K/129G did not cause local or systemic reactions and also failed to induce, in mice, potentiation of anaphylaxis, stimulation of histamine sensitivity or enhancement of insulin secretion. Furthermore, no toxicity on CHO cells was observed with concentrations up to $5 \mu \mathrm{g} / \mathrm{ml}$, even when PT-9K/129G was tested after storage for 4 months at $37^{\circ} \mathrm{C}$. As expected, the double mutant still retained the invitro mitogenic and haemagglutinating activities of wild type PT, which have been associated with the B-oligomer. ${ }^{12,13}$

To assess the best formulation to be included in a vaccine, we tested the immunogenic properties of PT-9K/129G before and after mild stabilisation with formaldehyde (PTF9K/129G) (table IV). Formalin treatment was used because of the reduction of the band in SDS-PAGE relative to the S1 subunit of PT-9K/129G, observed after long incubation periods at $37^{\circ} \mathrm{C}$. When tested for potency, the $\mathrm{Al}(\mathrm{OH})_{3}$ adsorbed PTF-9K/129G and the fluid PT-9K/129G protected mice, in a dose-dependent manner, from i.c. challenge with virulent $B$. pertussis. Moreover, a single injection in guinea-pigs of doses of $\mathrm{Al}(\mathrm{OH})_{3}$-adsorbed PTF-9K/129G, ranging from 3 to $50 \mu \mathrm{g}$, raised antibody levels which were
Table IV. Immunogenicity of $\mathrm{Al}(\mathrm{OH})_{3}$-adsorbed PTF-9K/ 129G (A) and fluid PT-9K/129G (B)

\begin{tabular}{|c|c|c|c|c|c|c|c|}
\hline \multirow{3}{*}{$\begin{array}{c}\text { Dose } \\
(\mu \mathrm{g} / \text { mouse })\end{array}$} & \multicolumn{2}{|c|}{$\begin{array}{c}\text { Survivors } \\
\text { after } \\
\text { i.c. challenge }\end{array}$} & \multirow{3}{*}{$\begin{array}{c}\text { Dose of A } \\
(\mu \mathrm{g} / \text { mouse })\end{array}$} & \multicolumn{4}{|c|}{$\begin{array}{l}\text { Serum antibody response } \\
\text { in guinea-pigs given }\end{array}$} \\
\hline & \multirow[t]{2}{*}{ A } & \multirow[t]{2}{*}{ B } & & \multicolumn{2}{|c|}{1 dose } & \multicolumn{2}{|c|}{2 doses } \\
\hline & & & & ABS & $\mathbf{N T}$ & ABS & NT \\
\hline 30 & $14 / 16$ & $16 / 16$ & - & 0.06 & $<2$ & - & - \\
\hline 12 & ND & $16 / 16$ & 3 & 1.9 & 20 & $2 \cdot 5$ & 1280 \\
\hline 6 & $14 / 16$ & ND & 10 & $2 \cdot 0$ & 20 & $3 \cdot 1$ & 1280 \\
\hline $4 \cdot 8$ & ND & $12 / 16$ & 25 & $2 \cdot 2$ & 20 & $3 \cdot 4$ & 1280 \\
\hline 1.9 & ND & $10 / 16$ & 50 & $2 \cdot 4$ & 80 & $4 \cdot 1$ & 1280 \\
\hline $1 \cdot 2$ & $8 / 16$ & $7 / 16$ & & & & & \\
\hline 0.2 & $2 / 16$ & $3 / 16$ & & & & & \\
\hline PD50 & $1 \cdot 2$ & $1 \cdot 1$ & & & & & \\
\hline
\end{tabular}

ABS, geometric mean of absorbance values of undiluted sera.

NT, toxin neutralising titres expressed as the highest dilution of serum that caused $100 \%$ inhibition of the clustering effect on CHO cells induced by $120 \mathrm{pg}$ of wild-type PT.

ND, not determined.

PD50, median protective dose.

32-40-fold higher than those before immunisation. A further $50 \%$ increase of the ELISA titres was observed in sera of animals given a second injection of toxoid; the antibodies obtained with as little as $3 \mu \mathrm{g}$ of PTF-9K/129G neutralised the CHO clustering effect of PT up to a dilution of 1280 .

These data provide evidence that the immunogenicity of PT is independent of its enzymatic activity. The double mutant PT-9K/129G is devoid of toxicity associated with the enzymatic activity of $\mathrm{S} 1$ subunit but is still highly immunogenic. Therefore we conclude that PT-9K/129G is an ideal candidate as a component for a new acellular vaccine against whooping cough. A phase-I clinical trial with 30 adult volunteers showed that this product is safe and induces high levels of toxin-neutralising antibodies.

\section{ADHESION OF B. PERTUSSIS}

\section{S. G. P. Funnell and A. Robinson}

\section{PHLS CAMR}

It has been reported ${ }^{14-16}$ that $B$. pertussis is capable of adhering to Vero (Green Monkey Kidney) cells in vitro. We have attempted to standardise this adhesion assay and investigate the minor adhesins involved and have found that FHA plays an essential role and that fimbriae (Fim 2,3) do not seem to be involved in this adhesion (table V). Several vaccines, including the CAMR acellular pertussis vaccine, can induce antibodies that inhibit adhesion of $B$. pertussis to Vero cells and each of the three separate components of the CAMR acellular vaccine (PT, FHA and Fim 2,3) can induce antisera that inhibit this adhesion (table VI). This model is currently being assessed in parallel with the murine intranasal vaccine protective potency test.

\section{DISSOCIATION OF B. PERTUSSIS FIMBRIAE}

\section{Irons, R. Seabrook and A. Robinson}

\section{PHLS, CAMR}

Biophysical and immunological methods have been used to study the relationship between $B$. pertussis fimbrial structure and antibody binding. Analytical ultracentrifugation of three different preparations of fimbriae purified from a serotype 1,2,3 strain showed that each sedimented as a 
Table V. Comparison of adhesion of $B$. pertussis mutant strains to Vero cells

\begin{tabular}{lc}
\hline B. pertussis strain no. & $\begin{array}{c}\text { Number of } \\
\text { bacteria/Vero cell } \dagger\end{array}$ \\
\hline Experiment $A$ & \\
Tn99 (Vir -) & 0 \\
W28 (Vir +) & 7 \\
Bp86(Fim 2,3-) & $49^{*}$ \\
Experiment B & \\
W28 (Vir +) & 23 \\
B862 (FHA -) & $0^{*}$ \\
B150(FHA -) & $0^{*}$ \\
Tohama (Vir + ) & 14 \\
\hline
\end{tabular}

*Significantly different $(\mathrm{p} \leq 0.01)$ from control strain W28.

$\dagger A$, Median obtained with each sample;

$B, \frac{\text { Median of control-Median of test }}{\text { Median of control }} \times 100$.

Table VI. Antibody mediated inhibition of adhesion

Immunogen $\begin{gathered}\text { Percentage inhibition of } \\ \text { adhesion }\end{gathered}$

\begin{tabular}{lc}
\hline JNIH3 & $100^{*}$ \\
(Japanese acellular) & $100^{*}$ \\
DTP & \\
(British whole cell) & $71^{*}$ \\
PVA & \\
(CAMR acellular) & $57^{*}$ \\
PT Toxoid & $100^{*}$ \\
FHA & $100^{*}$ \\
Fim 2,3 & \\
\hline
\end{tabular}

Results shown are the median of each sample: $\underline{\text { Median of control-Median of test }} \times 100$.

Median of control

*Significantly different $\mathrm{p} \leq 0.01$ from control strain W28.

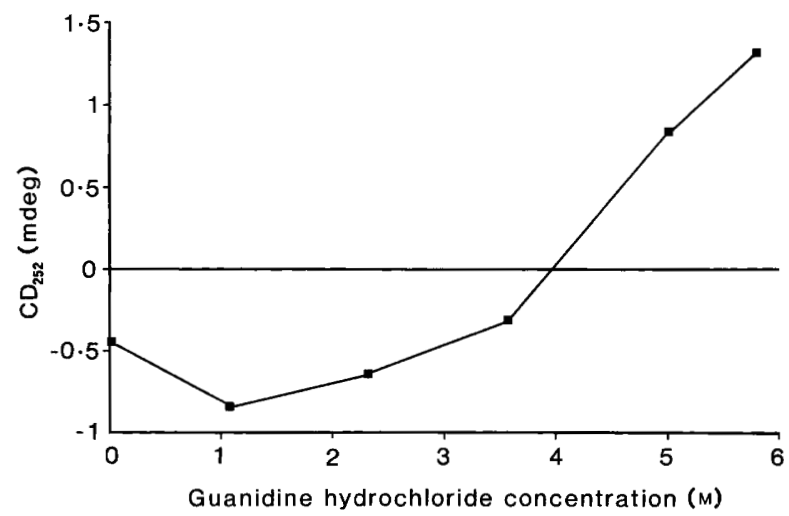

Fig. 7. Measurement of circulár dichroism at $252 \mathrm{~nm}$ (CD252) at various concentrations of guanidine hydrochloride.

single hypersharp peak with almost identical sedimentation coefficients (S20,W) and similar dependence of S20,W on protein concentration. The fimbriae were resistant to the effects of reagents that cause dissociation into subunits of fimbriae from other organisms. Disaggregation of bundles of $B$. pertussis fimbriae by alkaline $\mathrm{pH}$ allowed them to dissociate in $6 \mathrm{M}$ guanidine hydrochloride into subunits of about $c .20 \mathrm{Kda}$. A structural change involving tertiary chain folding which accompanied this dissociation was detected by measurement of Cotton effects in the near ultraviolet by circular dichroism spectroscopy (fig. 7). Antibodies to fimbrial synthetic peptides and MAbs or polyclonal antibodies recognised different structural forms of the $B$. pertussis fimbriae in ELISA and can be used to study different aspects of fimbrial structure.

THE NATURE OF AGGLUTINOGEN (AGG) 3 FROM B. PERTUSSIS

\section{J. H. Fredriksen}

\section{National Institute of Public Health, Oslo, Norway}

AGG 3 is one of the components claimed to be important in the pathogenesis of pertussis and thus considered to be one of the important components of a pertussis vaccine. Biochemical and electronmicroscopic analysis of this serotype-specific antigen has demonstrated a fimbrial structure. The native form of AGG 3 had a minimal absorbance at $280 \mathrm{~nm}$ and stained only weakly with Coomassie Brilliant Blue or silver in SDS-PAGE. After solubilisation, however, the protein was readily stained. Immunoblot studies have shown a ladder-like pattern for partly assembled $B$. pertussis fimbriae. Only the native, polymeric form of AGG 3 , or multiple oligomeric fimbrial units reacted in immunoblots with AGG 3-specific antibodies. The solubilised 23-Kda subunits did not bind AGG 3-specific antibodies. The solubilised subunit form, used as an immunogen in rabbits, produced antisera that reacted strongly with the subunit protein but not with the native or partly assembled fimbriae. When the polymeric form of AGG 3 was used as immunogen, specific antibodies were produced that were directed against native or partly assembled AGG 3 . In conclusion, the experimental evidence showed that the AGG 3 antibodybinding activity depended on conformational epitopes (probably the quaternary structure) of the fimbriae, and that the epitopes present on the solubilised subunits were of minor importance in the serological discrimination of AGG 3. Further studies on the nature of epitopes specific for native AGG 3 are necessary in relation to the preparation of this antigen for diagnostic and vaccine purposes.

\section{PHYSICAL AND ANTIGENIC VARIATION IN BORDETELLA} LIPOPOLYSACCHARIDE ENDOTOXINS

\section{Ava Ray, K. Redhead, Susan Selkirk and S. Poole \\ National Institute for Biological Standards and Control}

Lipopolysaccharide (LPS) preparations from $B$. pertussis strains W28, 18323 phase I and IV, and 134 phase I and IV were compared for reactogenicity in the Limulus amoebocyte lysate assay and in the human mononuclear cell response test. All B. pertussis LPS preparations gave the same or lower responses in these tests than $E$. coli endotoxin which is currently used as the standard. SDS-PAGE (acrylamide 15\% running gel) separation of LPS preparation from Bordetella spp. is shown in fig. 8. Antigenicity of B. pertussis LPS was tested by Western blotting. Preparations from strains W28 and $18323 \mathrm{I}$ were resolved into LPS $\mathrm{a}$ and $\mathrm{b}$ and in both cases the former was bound by MAbs raised to strain W28 and various polyclonal sera, from both vaccinated and infected mice.

\section{Properties of $B$. PERTUSSIS ADENYLATE CYCLASE} EXPRESSED IN $E$. COLI

R. M. Brownlie, J. G. Coote, R. Parton, A. Rogel*, A. Goldschmidt* and E. Hanski*

Microbiology Department, University of Glasgow, and *Weizmann Institute of Science, Rehovot, Israel

$B$. pertussis produces an adenylate cyclase (AC) toxin which enters mammalian cells where it is activated by 


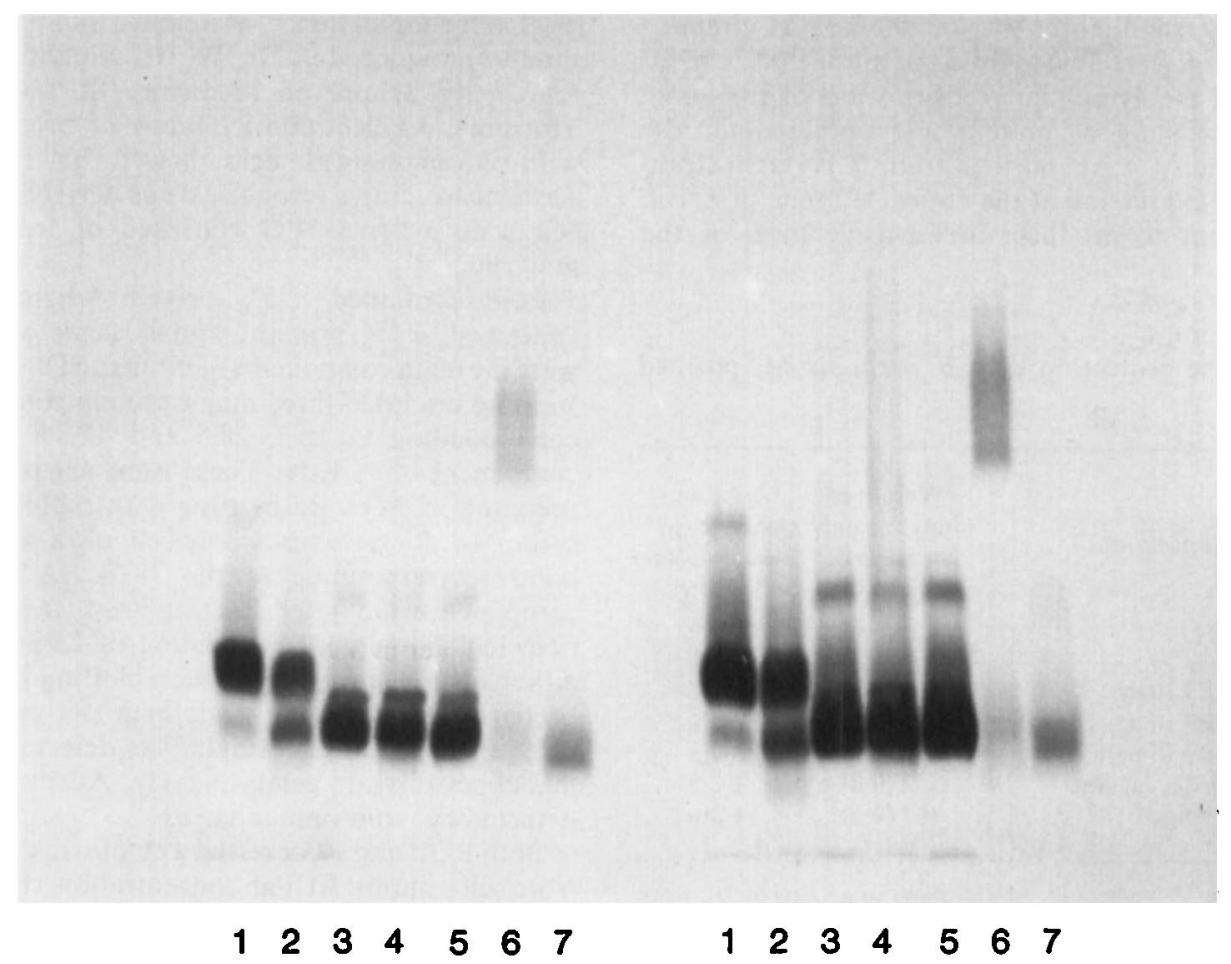

Fig. 8. SDS-PAGE of LPS preparations from five strains of Bordetella. Lane 1, B. pertussis W28; 2, B. pertussis $18323 \mathrm{I} ; 3$, B. pertussis 18323 IV; 4 , B. pertussis 18323 I; 5 , B. pertussis 134 IV; 6 , B. parapertussis; 7 B. bronchiseptica. The seven left hand wells were loaded with LPS $2 \mu \mathrm{g} /$ well and those on the right hand side with $5 \mu \mathrm{g} / \mathrm{well}$.

A

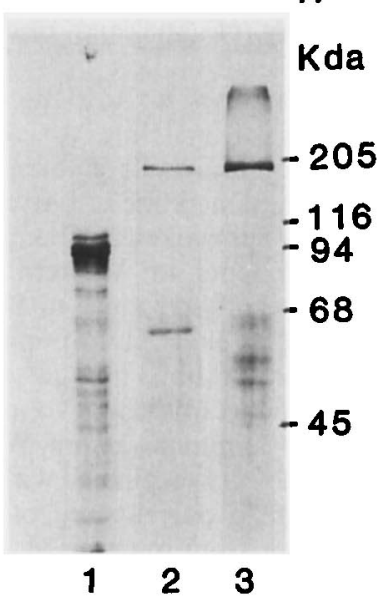

B

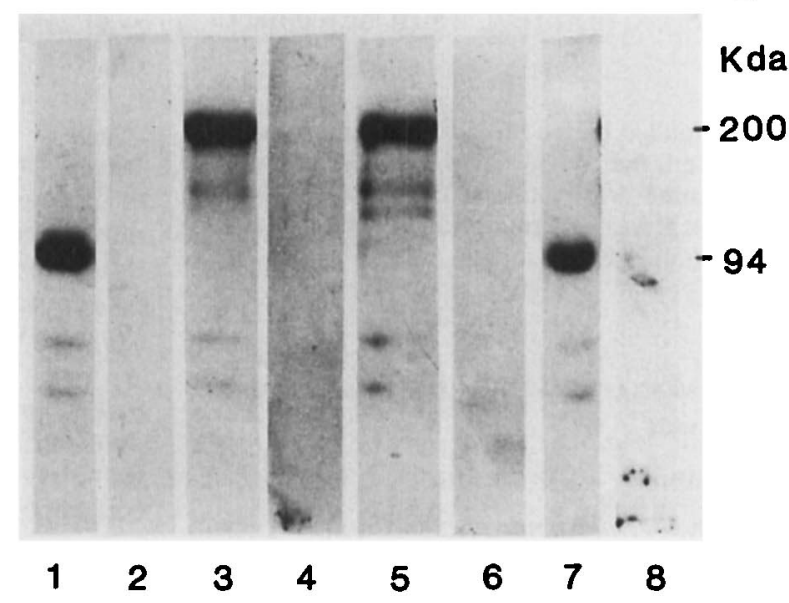

Fig. 9. SDS-PAGE and immunoblotting of AC expressed in E. coli. A. Samples (2-4 $\mu \mathrm{g})$ of purified AC were subjected to SDS-PAGE and silver stained. Lane 1, E. coli pRMB9 clone; 2, B. pertussis $165 ;$ e, E. coli pRMB3 clone. Arrows show mol. wt standards (Kda). B. Crude extract $(50 \mu \mathrm{g})$ or purified AC $(0.2 \mu \mathrm{g})$ was subjected to SDS-PAGE, the proteins were transferred to nitrocellulose and incubated with either $B$. pertussis AC antiserum (18) diluted 1 in 500 (lanes 1,3,5 and 7) or control serum (lanes 2,4,6 and 8). Lanes 1 and 2, purified AC from pRMB9; 3 and 4, purified AC from pRMB3; 5 and 6, crude extract from pRMB3; 7 and 8, crude extract from pRMB9. Antibodies were detected by ${ }^{125} \mathrm{I}$-labelled protein $\mathrm{A}$ and autoradiography. Arrows indicate respective mol. wts.

calmodulin. Previous work ${ }^{17}$ achieved efficient expression of cloned $B$. pertussis $\mathrm{AC}$ in $E$. coli to a specific activity comparable with that in native $B$. pertussis. The invasive and immunogenic properties of AC purified from $E$. coli have been examined.

The recombinant $\mathrm{AC}$ was produced by plasmids pRMB3 and $\mathrm{pRMB} 9$ which encode the entire AC gene and $2.6 \mathrm{~kb}$ from the $5^{\prime}$ end respectively. ${ }^{17}$ The expression of AC in $E$. coli from these plasmids depended on the lac promoter contained in the vector. All experimental procedures have been described previously. ${ }^{17-19}$
Plasmids pRMB3 and pRMB9 were transformed into Lon $^{-} E$. coli $\mathrm{H} 1469$ to minimise proteolytic degradation of AC. SDS-PAGE of purified AC from these strains revealed protein bands of 94 and $200 \mathrm{Kda}$ for $\mathrm{AC}$ purified from pRMB9 and pRMB3 respectively (fig. 9). The 200-Kda protein purified from $E$. coli (pRMB3) migrated on SDSPAGE to a position identical with that of the high mol. wt AC purified from $B$. pertussis (fig. 9A). Both the 94- and 200Kda proteins produced in $E$. coli reacted specifically, either in crude extracts or in the purified form, with polyclonal antiserum raised against $\mathrm{AC}$ purified from $B$. pertussis 
(fig. 9B). However, neither the 94- nor 200-Kda AC proteins expressed in $E$. coli were able to raise the intracelluar cAMP concentration of S49 lymphoma cells (a value of $10.6 \mu \mathrm{mol}$ of $\mathrm{cAMP} / 10^{7}$ cells $/ \mathrm{mg}$ of protein was obtained for the penetrative capacity of AC purified from $B$. pertussis strain 165). Therefore, expression of the entire AC gene in $E$. coli was not sufficient to produce the invasive form of the enzyme.

Table VII. Mouse protection with $B$. pertussis AC purified from $E$. coli

\begin{tabular}{|c|c|c|}
\hline Vaccine preparation & $\begin{array}{l}\text { Weight of } \\
\text { lungs as per- } \\
\text { centage of } \\
\text { body wt (SD) }\end{array}$ & $\begin{array}{l}\text { Mean wt.- } \\
\text { change (g) } \\
2 \text { weeks after } \\
\text { challenge }\end{array}$ \\
\hline $\begin{array}{l}\text { Unvaccinated } \\
\text { E. coli }(\text { lon) pRMB3 } 10 \mu \mathrm{g} \\
\text { E. coli }(\text { lon) pRMB9 } 10 \mu \mathrm{g} \\
\text { E. coli }(\text { lon) pRMB9 } 25 \mu \mathrm{g} \\
\text { Whole cell B. pertussis vaccine } \\
\text { Controls: not challenged }\end{array}$ & $\begin{array}{l}2 \cdot 9(1 \cdot 8) \\
2 \cdot 1(1 \cdot 25) \\
3 \cdot 7(0 \cdot 9) \\
3 \cdot 7(1 \cdot 3) \\
1 \cdot 2(0 \cdot 6) \\
0 \cdot 7(0 \cdot 1)\end{array}$ & $\begin{array}{l}-0.1 \\
+1.7 \\
-0.1 \\
-0.3 \\
+2.5 \\
+2.6\end{array}$ \\
\hline
\end{tabular}

Female CD-1 mice, 3 weeks old, randomised in groups of 10 , were vaccinated with purified AC 10 or $25 \mu \mathrm{g} /$ mouse or whole cell vaccine $5 \mathrm{ml} /$ mouse; 2 weeks after vaccination, the mice were challenged intranasally with $B$. pertussis $18323 \mathrm{c} .10^{6} \mathrm{cfu}$. Mice were assessed for infection 2 weeks after challenge.

Preliminary evidence (table VII) established partial protection in 3-week-old mice vaccinated with AC ( $200 \mathrm{Kda})$ purified from E. coli (pRMB3) and challenged intranasally at 5 weeks. No protection was afforded by the 94-Kda protein purified from $E$. coli (pRMB9), which lacked the Cterminal portion of $\mathrm{AC}$.

Work in the UK was funded by the Medical Research Council, Immuno Ag, Austria and the Wood Boyd Fund of Glasgow University. Work in Israel was supported by the US-Israel Cooperative Development Research Program and the US Israel Binational Science Foundation.

\section{CYTOTOXIC ACTIVITY ASSOCIATED WITH THE PEPTIDOGLYCAN FRACTION OF B. PERTUSSIS}

\section{Antionette M. Abraham, M. J. Corbel and D. J. Hockley \\ National Institute for Biological Standards and Control}

It has been suggested that tracheal cytotoxin (TCT), a muramyl peptide thought to be derived from $B$. pertussis cell-wall peptidoglycan (PG), ${ }^{20}$ plays a major role in the pathogenesis of disease produced by this organism. ${ }^{21,22}$ In particular, the action of TCT may account for the damaging effect of $B$. pertussis infection on the ciliated epithelium of the upper respiratory tract and for the characteristic persistent cough. ${ }^{21-23}$

The production of TCT in vitro is readily detected in supernatant medium from $B$. pertussis cultures. ${ }^{20-22}$ It is assumed from the composition of TCT that it is produced by enzymatic hydrolysis of cell-wall PG. ${ }^{20,23}$ However, the toxicity of PG itself appears to have received little attention. This is potentially significant in relation to whole-cell pertussis vaccines, which inevitably have a high content of cell-wall material.

The protein complex of PG (PGP) was prepared from phase I and phase IV cells of $B$. pertussis strain DCHI/J by extraction with trichloroacetic acid and hot SDS. PG was recovered from this by digestion with proteinase $K$ after brief ultra-sonication. ${ }^{24}$ Reference samples of TCT were kindly provided by $\mathrm{Dr}$ W. E. Goldman, Washington University School of Medicine, St Louis, MO, USA. Transmission electronmicroscopy of preparations stained with phosphotungstic acid showed that PGP consisted of saccular structures recognisable as derived from $B$. pertussis cell walls whereas PG consisted of fragmented fibrous material.

PGP contained c. $5 \%$ protein whereas PG fraction contained $<2 \%$ protein; amino sugar and carbohydrate were the main components identified. SDS-PAGE and silver staining disclosed three major protein components in PGP corresponding to $18.5,28.5$ and $42.5 \mathrm{Kda}$ and a minor component of $71 \mathrm{Kda}$. These were not present in the PG preparation. Western blotting with rabbit polyclonal antiserum to $B$. pertussis whole-cell ultra-sonicate disclosed bands corresponding to the $18 \cdot 5-, 28 \cdot 5-$ and $42 \cdot 5-\mathrm{Kda}$ components, the latter reacting most strongly; PT was not detected. No significant amount of LPS was revealed by either silver staining or Western blotting in the PGP or PG preparations, although endotoxin activity equivalent to c. $1 \%$ of the total dry weight was detected by the Limulus amoebocyte lysate gelation assay. Adenyl cyclase was not detected by radio-immunoassay.

Both PGP and PG exerted a cytotoxic effect on $\mathrm{CHO}$ and Vero cell cultures. At high concentration, the cells completely disappeared. At concentrations of $1-5 \mathrm{mg} / \mathrm{ml}$, bizarre cellular forms were produced. These effects were quite unlike those produced by pertussis toxin (fig. 10). Purified $B$. pertussis LPS (endotoxin), even at concentrations greatly exceeding those present in the PG and PGP preparations, did not produce similar effects. TCT at concentrations cytotoxic for hamster tracheal ciliated cells $(1 \mu \mathrm{M})$ did not exert a similar effect on CHO cells.

The effect of PG and PGP on organ cultures of chick embryo trachea was similar to that of $B$. pertussis whole cells, producing expulsion of cilia and rounding of the cells (fig. 11).

PGP and PG in doses up to $5 \mathrm{mg}$ given i.v. did not produce any signs of systemic toxicity in NIH mice. Intradermal injection into adult or young mice also failed to disclose any local dermonecrotic activity. PGP was antigenic in mice and rabbits but evoked antibody reacting with only the protein components in Western blot and ELISA procedures. No antibody response to PG was detected by Western blotting, solid phase radio-immunoassay or ELISA with sera from mice or rabbits immunised with PG or PGP in Freund's incomplete adjuvant. No antibody to PG was detected by radio-immunoassay or Western blotting in human sera from subjects vaccinated with $B$. pertussis wholecell vaccine or with a past history of pertussis. Neither human sera nor sera from immunised animals neutralised the cytotoxic effects of PG, PGP or TCT on tissue cultures.

No differences were observed in the properties of PG prepared from phase I and phase IV $B$. pertussis cells.

Both PG and PGP inhibited DNA synthesis (incorporation of ${ }^{3} \mathrm{H}$-thymidine), RNA synthesis (incorporation of ${ }^{3} \mathrm{H}$ uridine) or protein synthesis (incorporation of ${ }^{3} \mathrm{H}$-serine) by $\mathrm{CHO}$ cells. At limiting concentration $(c .100 \mu \mathrm{g} / \mathrm{ml})$ the effect on protein synthesis was reduced but DNA and RNA synthesis were still inhibited. The effect of PG and PGP on ciliated epithelial cells was similar to that reported for TCT. ${ }^{21-23}$ However, TCT has not been reported to exert cytotoxic activity on $\mathrm{CHO}$ or Vero cell cultures and produced no such effect in the present study. It is possible that the effects produced by PG preparations on ciliated and nonciliated cells were mediated by different effectors. The mechanism of action of PG at the molecular level appeared somewhat different from that reported for TCT $^{21}$ in that both DNA and RNA synthesis were inhibited.

Although very high concentrations of PG and PGP were required to produce a cytotoxic effect, these probably bore 

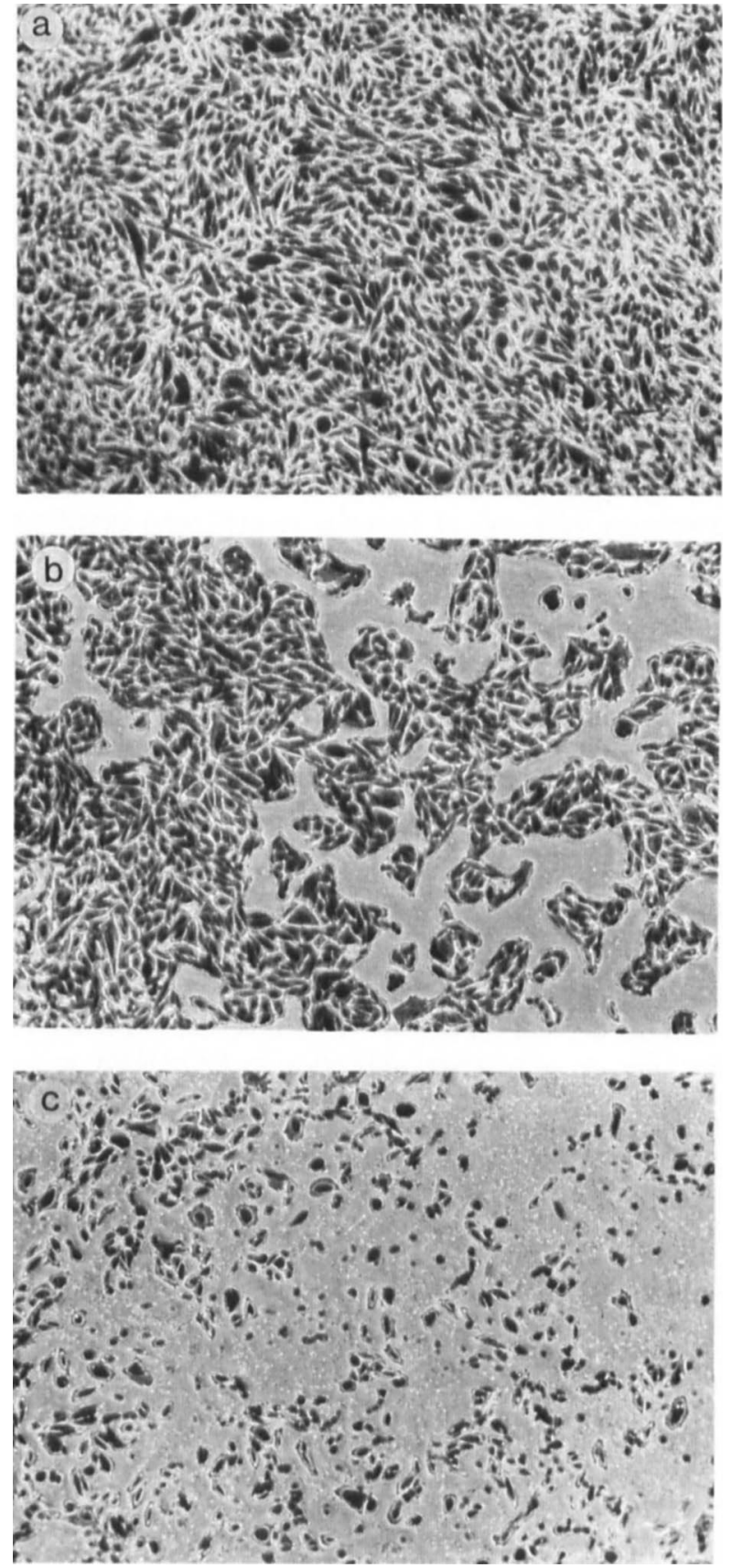

Fig. 10. Cytotoxic effect of $B$. pertussis on $\mathrm{CHO}$ cells. a, Normal CHO cells; b, clumping effect of PT $8 \mathrm{ng} / \mathrm{ml} ; \mathbf{c}$, cytotoxic effect of PG $12.9 \mathrm{mg} / \mathrm{ml}$. H\&E, $\times 125$.

little relationship to the actual concentrations of active material. The nature of this was not determined but some cytotoxic activity was present in the supernate from cell cultures incubated in contact with PG preparations. However, the bulk of the latter remained as an insoluble residue. This suggests that the active material was a soluble degradation product or mixture of products possibly including TCT. No other known toxin of $B$. pertussis was present in PG preparations in sufficient concentration to account for the cytotoxic activity.

The lack of activity in vivo, even at high concentrations, and the relatively low toxicity of the PG and PGP fractions, several orders of magnitude less than PT, does not suggest that these components are likely to make a significant contribution to vaccine toxicity.
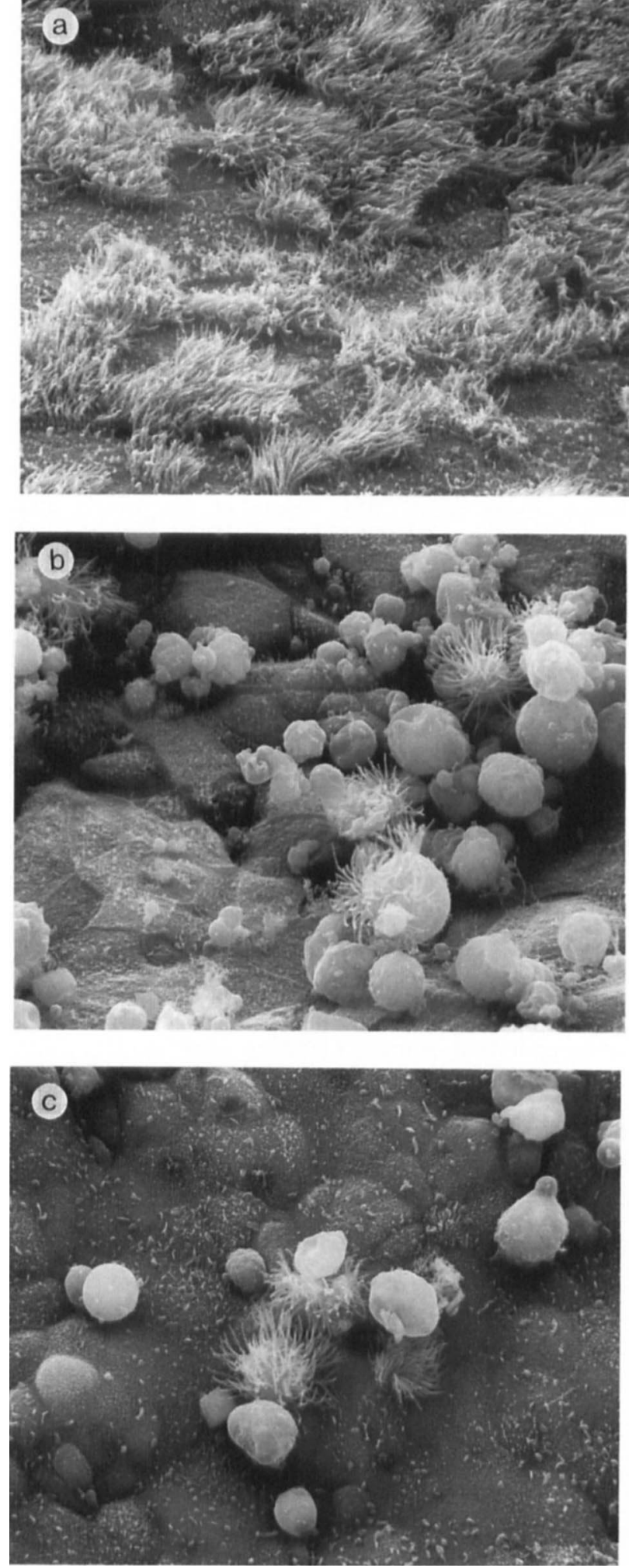

Fig. 11. Cytotoxic effect of $B$. pertussis (PG) on chick embryo tracheal organ culture (scanning electronmicrograph; $\times 1500$ ). a, negative control ( $24 \mathrm{~h})$; $\mathbf{b}$, cytotoxic effect of whole $B$. pertussis cells $(24 \mathrm{~h}) ; \mathrm{c}$, cytotoxic effect of PG (24 h).

IDENTIFICATION OF AN IMMUNODOMINANT REGION OF THE PROTECTIVE PROTEIN P. 69 FROM B. PERTUSSIS

I. G. Charles, G. Dougan, D. J. Pickard, M. Francis*, D. Campbell*, M. A. Romanos, K. M. Beesley, M. Brennan†, C. Manclark $\dagger$, M. Au Jensen $\ddagger$ I. Heron $\ddagger$ N. F. Fairweather, A. Chubb and P. Novotny 
Departments of Molecular Biology and *Virology, Wellcome Biotech, Beckenham, Kent, BR3 3BS, +Division of Bacterial Products, National Centre for Drugs and Biologics, FDA, Bethesda, MD, 20892, USA, and †Statens Seruminstitut, Amager Boulevard 80, 2300 Copenhagen S, Denmark

The outer-membrane protein P. 69 (69-Kda protein) of $B$. pertussis is one of the virulence factors believed to contribute to the disease state of whooping cough. Preparations of P. 69 are protective in mice, in the i.c. challenge test, and a MAb, BB05, raised against an homologous protein, P. 68 from $B$. bronchiseptica, is capable of conveying passive protection in mice against an aerosol challenge. To map the epitope for this protective MAb BB05 and other cross-reacting MAbs against P. 68 and P. 69, we constructed, and expressed in $E$. coli, a series of amino- and carboxy-terminal deletion mutants. MAbs bound predominantly to a region of P. 69 spanning a (PRO-GLN-PRO) $)_{5}$ repeat motif. One MAb bound to a region of P. 69 scanning a (GLY-GLY-X ${ }_{a a}-X_{a a}-$ $\mathrm{PRO})_{5}$ repeat motif. This region of the protein also encompasses an ARG-GLY-ASP motif, a surface-exposed sequence implicated in receptor-mediated adhesion for various eukaryotic and prokaryotic adhesins. To delineate further the MAb binding site around the (PRO-GLN-PRO) region, a panel of overlapping synthetic peptides and a 30amino acid hepatitis B-core fusion protein were synthesised. Of the nine MAbs tested, five bound to amino-acid sequences spanning the region centred around the (PRO-GLN-PRO) sequence. These observations suggest that the immunodominant region of the protective protein P. 69 is within the region around this (PRO-GLN-PRO) $)_{5}$ sequence, and the protective MAb BB05 binds within the 23-amino-acid protein sequence: ALA-PRO-GLN-PRO-GLY-PRO-GLNPRO-PRO-GLN-PRO-PRO-GLN-PRO-GLN-PRO-

GLU-ALA-PRO-ALA-PRO-GLN-PRO. Human serum, specific for the P. 69 antigen, also reacted predominantly with this peptide sequence. The finding of a linear epitope corresponding to the major immunodominant region of the protective protein P. 69 has implications for understanding of the immune response to whooping cough.

\section{PROSPECTS FOR ACELLULAR PERTUSSIS VACCINE BASED ON 69-} KDA PROTEIN

P. Novotny, A. P. Chubb, K. Cownley, I. G. Charles, C. A. Hart*, M. E. Macaulayt and F. V. Skvaril $\ddagger$

Wellcome Research Laboratories, Beckenham, Kent, ${ }^{*}$ Department of Medical Microbiology, Liverpool University, $+P H L S$, Withington Hospital, Manchester and $\ddagger W H O$ Ig-Subcommittee, Berne, Switzerland

The acellular $B$. pertussis vaccines prepared in Japan by Biken, such as PPP 3 or J-NIH 6, or an experimental vaccine prepared according to the Takeda formula by Connaught Laboratories Ltd, (provided by L. K. Gordon), when tested in the classical Kendrick potency test (i.e., i.c. challenge of $\mathrm{N}$ : NIH-S mice 14 days after a single dose of antigen showed very weak protective efficacy despite the fact that all of them contained detectable amounts of free lymphocytosis promoting factor (LPF, PT, pertussigen). However, when these vaccines were enriched by the addition of the isolated 69$\mathrm{Kda}$ protein of $\boldsymbol{B}$. pertussis ${ }^{25}$ their potency was increased significantly $(p<0.01)$ to the level of the whole-cell British reference vaccine $66 / 84$. The protective efficacy of the isolated $69-\mathrm{Kda}$ protein alone was variable and, with even the most effective preparations, a relatively high dose of the protein would be necessary for protection equivalent to that given by the whole-cell reference preparation. Since it is assumed that the presence of LPF, although non-protective on its own, is essential in small, non-toxic quantities, to render any vaccine effective in the Kendrick test, ${ }^{26}$ pure 69 -
Kda protein and the FHA was prepared from two LPFdeleted mutant strains: BP537 (kindly provided by E.L. Hewlett, University of Virginia, USA) and W28 $\triangle$ toxin (kindly provided by R. Rappuoli, Sclavo Research Centre, Italy) which yielded preparations free of any LPF. The purified LPF was prepared according to the method of Svoboda et al. ${ }^{27}$ By testing these B.pertussis cell-components it became clear that the combination of the $69-\mathrm{Kda}$ protein and FHA was highly protective in the Kendrick test. To achieve an analogous protective effect with the combination of the 69-Kda protein and LPF, about 18 times more 69$\mathrm{Kda}$ protein would be needed. None of the components alone or the FHA + LPF combination gave sufficient protection. These data suggest that, in order for an acellular vaccine to be protective in the Kendrick test it does not need the presence of any amount of LPF-an observation consistent with that of Bartolini et al. ${ }^{28}$ who tested the mutant strain W28 $\triangle$ tox (which does not produce any LPF) as a whole-cell vaccine. The concept that LPF is essential for mouse protection is wrong and has possibly perverted the current trends in acellular pertussis vaccine research.

Since a vaccine formulated from $c .15 \mu \mathrm{g}$ each of $69-\mathrm{Kda}$ protein and FHA had a protective potency equivalent to $4 \mathrm{IU}$ (as related to the whole-cell British reference 66/84) this combination is proposed as a candidate acellular vaccine. Sequential preparations of the $69-\mathrm{Kda}$ protein were, however, variable. For the assessment of the quality of the protein in vitro, several properties of the $69-\mathrm{Kda}$ protein were exploited. These were: (i) chromatofocusing pattern, (ii) binding of the protein to human lymphocytes, and (iii) its affinity for NAD. Although these may represent some qualitative indicators, none of them alone or in combination can replace the Kendrick test. Formalin or glutaraldehyde treatment appears to be detrimental to the protective properties of the $69-\mathrm{Kda}$ protein (and possibly to FHA). This may explain why acellular vaccines prepared in Japan, which sometimes contain up to $5-10 \%$ of the $69-\mathrm{Kda}$ protein, are not protective in the Kendrick test (and, possibly, not in children)

The justification of the proposed vaccine composition is corroborated by the analysis of antibodies in sera of nonvaccinated children collected during various phases of whooping cough confirmed by a positive culture. The antiLPF antibodies of all isotypes (IgG, IgM, IgA) developed very quickly, a few days after onset of disease, whereas anti69-Kda and anti-FHA antibodies developed more slowly with the appearance of the IgM antibodies first, followed by a rather slow development of $\mathrm{IgG}$ and $\mathrm{IgA}$ antibodies. AntiLPS antibodies were predominantly $\operatorname{IgM}$ and $\operatorname{IgA}$. The predominant IgG subclass was $\operatorname{IgG}_{1}$. Surprisingly, anti-69$\mathrm{Kda}$ protein antibody was $c .90 \% \mathrm{IgG}_{1}$ and $10 \% \mathrm{IgG}_{4}$.

\section{CONSTRUCTION AND CHARACTERISATION IN VIVO OF $B$. PERTUSSIS AROA MUTANT STRAINS}

\section{Roberts, D. Maskell*, P. Novotny and G. Dougan*}

Department of Molecular Biology, Wellcome Research Laboratories, and ${ }^{*}$ Molecular Infectious Diseases Group, Institute of Molecular Medicine, John Radcliffe Hospital, Headington, Oxford $O X 39 D U$

A DNA fragment encoding a kanamycin-resistance determinant was used to insertionally inactivate the cloned aro $A$ gene of $B$. pertussis in $E$. coli $\mathrm{K} 12$ and a conjugative shuttle vector system based on the suicide vector $\mathrm{pRTP1}$ was used to deliver the mutations from $E$. coli back into $B$. pertussis strains CN2992 and BP1. The aroA mutation was introduced by allelic exchange into the chromosome of $B$. pertussis resulting in otherwise isogenic parental and $B$. pertussis aro $A$ mutant pairs. The $B$. pertussis aro $A$ mutant strains grew well on laboratory medium supplemented with 
aromatic compounds but failed to grow on unsupplemented medium. The $B$. pertussis aro $A$ mutant strains expressed the normal $B$. pertussis extracellular, virulence-associated proteins and inactivated, whole-cell vaccine prepared with the mutant strains protected mice as efficiently as the parent strains against i.c. challenge with the virulent $B$. pertussis strain 18323 . The lungs of $\mathrm{NIH} / \mathrm{S}$ mice challenged with an aerosol containing live $B$. pertussis aro $A$ bacteria were inefficiently colonised compared to the lungs of a similar group of mice exposed to an aerosol containing the live parent $B$. pertussis bacteria. Mice exposed to three separate aerosols of live $B$. pertussis aro $A$ bacteria were protected against lung colonisation after exposure to an aerosol containing the parent $B$. pertussis strain.

\section{A NEW ACELLULAR PERTUSSIS VACCINE}

\section{J. R. Vose}

Connaught Laboratories Ltd, Willowdale, Ontario M2R 3T4, Canada

$B$. pertussis whole-cell vaccine, although effective in conferring protection against whooping cough, produces several undesirable reactions. The occurrence of these has prompted the search for a less reactogenic acellular pertussis vaccine composed of purified bacterial antigen(s).

A simple novel process has been developed for the simultaneous purification of PT, FHA and $69-\mathrm{Kda}$ antigens by chromatography on filter aid (Perlite). The remaining impurities are further separated by hydroxylapatite chromatography. Finally, PT is detoxified with glutaraldehyde, while any residual PT $(<1 \%)$ present in the FHA fraction is detoxified with formaldehyde.

The process is economical (Perlite and hydroxylapatite are relatively inexpensive) and does not involve the use of harmful chemicals or blood components. The resultant toxoids are non-pyrogenic in the rabbit pyrogen test and do not revert to toxicity. The process also permits the purification of fimbriae for inclusion in a candidate acellular pertussis vaccine. A vaccine composed of purified, toxoided PT and FHA in combination with purified fimbriae $(2+3)$ and the $69-\mathrm{Kda}$ protein is protective in the mouse i.c. challenge test.

The initial antibody response to the PT component of the test vaccine was shown to be dose-dependent. However, after three injections, there was no significant difference in response between the lowest $(2.5 \mu \mathrm{g})$ and the highest $(20 \mu \mathrm{g})$ dose, as measured by a specific ELISA. In contrast, the antibody response measured by CHO cell antitoxin titres, was significantly higher to doses of $\geq 10 \mu \mathrm{g}$, than to doses of $\leq 5 \mu \mathrm{g}$. FHA antibody titres were similar for all doses tested. After three injections, there was no difference in antibody response to AGG between the test vaccine and the wholecell vaccine. Antibody responses to PT, FHA, AGG and 69Kda protein were not affected by the inclusion of $D$ and $T$. There was also no difference in antibody response to the PT and FHA antigens between this candidate 4-component vaccine and the Biken JNIH 6 vaccine.

\section{DEVELOPMENT AND CLINICAL TRIALS OF AN ACELLULAR PERTUSSIS VACCINE}

\section{J. Petre, C. Capiau and H. Bogaerts}

\section{Smith Kline Biologicals, B 1330 Rixensart, Belgium}

We have developed an acellular pertussis vaccine which contains highly purified PT (as toxoid) and FHA. $B$. pertussis cells were grown in a fermentor in a modified Stainer-Scholte medium containing methyl- $\beta$-cyclodextrin. The antigens were co-extracted by a batch procedure and purified by commercially available sorbents, without use of affinity sorbents based on serum glycoproteins. Both antigens were obtained in highly purified form, substantially free of endotoxin, with PT showing only the five subunits and FHA predominantly the $220-\mathrm{Kda}$ component when analysed by SDS-PAGE. They were inactivated separately. The inactivated antigens were free of toxic activities and were stable upon storage at $4^{\circ} \mathrm{C}$ or incubation at $37^{\circ} \mathrm{C}$. Vaccine doses were formulated with PT 8 or $25 \mu \mathrm{g}$ and FHA $25 \mu \mathrm{g}$ (as protein) and adsorbed in saline to $\mathrm{Al}(\mathrm{OH})_{3}$ as adjuvant.

The safety of this vaccine was first established in adult volunteers given one injection. It was well tolerated and induced a strong booster-type antibody response to both antigens. Further safety and immunogenicity studies were performed in 13-21-month-old children receiving a booster injection after a three-dose primary course of whole-cell DTP. These studies were performed either by simultaneous administration of DT and acellular pertussis component vaccine at separate injection sites or by administration of combined acellular DTP. In both cases, the local and general reactions were mild. A strong immune response was obtained to $\mathrm{D}$ and $\mathrm{T}$ toxoids and to both acellular pertussis components. Primary vaccination and dose-finding studies are being undertaken in several study centres.

\section{EFFICACY OF ACELLULAR PERTUSSIS VACCINES IN SWEDEN}

J. Storsaeter, C. P. Farrington*, H. Hallandert, E. Miller* and P. Olin

Sachs' Children's Hospital, Stockholm, Sweden, *PHLS Communicable Disease Surveillance Centre, London, and † National Bacteriological Laboratory, Stockholm, Sweden

A placebo-controlled double-blind efficacy trial of two acellular pertussis vaccines, both developed by the National Institute of Health in Japan (JNIH), was terminated on 26 Aug. 1987. Estimated efficacy against culture-verified pertussis was lower than expected for both vaccines- $54 \%$ for the monocomponent vaccine JNIH-7 (containing formaldehyde-inactivated PT) and $69 \%$ for the two-component vaccine JNIH-6 (containing both FHA and PT).

A secondary analysis, based upon sensitive serological criteria for diagnosis of pertussis infection, showed that both vaccines gave $c .80 \%$ protection against laboratory confirmed whooping cough with more than 3 weeks of paroxysmal coughing during the blind trial (1986-1987). The twocomponent vaccine JNIH-6 also gave some protection against atypical or asymptomatic pertussis infection, whereas the monocomponent vaccine JNIH-7 did not.

The trial cohort has been under non-blinded passive surveillance from 27 Aug. 1987 until 10 Sept. 1989. During this period 22 cases of culture-verified pertussis occurred in the JNIH-6 group $(n=1365)$, compared with 34 cases in the JNIH-7 group $(n=1370)$, and 68 cases in the placebo group $(n=882)$. Efficacy of JNIH-7 was estimated to be $68 \%(95 \%$ CI 52,78$)$ and the efficacy of JNIH- 6 to be $80 \%(95 \%$ CI 68 , 87).

Efficacy estimates based on parental reporting of whooping cough by mail questionnaires every 6 months during 2 years of post-trial follow-up were $73 \%(95 \%$ CI 63,80$)$ for JNIH-7 and $82 \%(95 \%$ CI 75,88$)$ for JNIH-6. Historical comparison with studies in which similar surveillance techniques were used indicated that the two acellular vaccines studied may protect against typical whooping cough to the same extent as whole-cell vaccines.

\section{POTENTIATION OF THE POTENCY OF TETANUS TOXOID BY PERTUSSIS VACCINE}

K. Redhead, T. A. Hill and J. T. Watkins

National Institute for Biological Standards and Control

The results of a collaborative study ${ }^{29}$ showed that although the estimates of potency for tetanus toxoid, both alone or as 
part of combined diphtheria-tetanus (DT) vaccine, obtained in mice and guinea-pigs were similar, the estimates of potency of the same tetanus component of a diphtheriatetanus-pertussis (DTP) vaccine obtained in mice were c. $75 \%$ higher than those obtained in guinea-pigs. It is generally assumed that this phenomenon is because mice have a high sensitivity to the adjuvanting effects of endotoxin or PT, or both, present in whole-cell pertussis vaccines. This raises the question of whether the new acellular pertussis vaccines, which contain very little endotoxin or active $\mathrm{PT}$, should be treated as DTP or DT only vaccines with regard to the potency requirements for the tetanus component.

Table VIII. Potency estimates for diphtheria and tetanus components

\begin{tabular}{l|ccc}
\hline \multirow{2}{*}{ Vaccines } & \multicolumn{3}{|c}{ Potencies (I.U.) } \\
\cline { 2 - 4 } & $\begin{array}{c}\text { Diphtheria } \\
\text { toxoid in } \\
\text { guinea-pigs }\end{array}$ & $\begin{array}{l}\text { Tetanus toxoid Tetanus toxoid } \\
\text { in guinea pigs }\end{array}$ \\
in mice
\end{tabular}

The immune responses to four vaccines were examined in mice and guinea-pigs. All four vaccines contained the same amount of diphtheria toxoid. Vaccines DT1 and DTP1 contained the same amount of the same tetanus toxoid and DT2 contained the same amount of the same batch of tetanus toxoid as vaccine DTP2. DTP1 contained a wholecell pertussis component and DTP2 contained an acellular pertussis component. The results of assays for diphtheria and tetanus potencies of the four vaccines are shown in table VIII. The acellular pertussis component had no effect on the potency assays of the diphtheria or tetanus toxoids in either mice or guinea-pigs. The whole-cell pertussis component, while also having no effect on the potency of the diphtheria toxoid, did have an effect on the potency of the tetanus toxoid inducing an increase of $150 \%$ when assayed in mice and an increase of $130 \%$ when assayed in guinea-pigs.

Sera from guinea-pigs and mice which had received the highest vaccine doses were checked for levels of serum antibodies to diphtheria and tetanus toxoids by ELISA and IRMA. The acellular pertussis component had no significant effect on the serum antibody levels to diphtheria or tetanus in either guinea-pigs or mice. The effect of the whole-cell pertussis component on serum antibody levels in guineapigs was not clear cut, however, it did appear to induce higher responses to both diphtheria and tetanus toxoid in mice.

The sera are now being assayed for toxin neutralisation. From these results it appears that DT acellular $P$ vaccines can be considered as DT only vaccines as regards requirements for tetanus potency.

DIAGNOSIS OF $B$. PERTUSSIS INFECTION BY USE OF A DNA PROBE WITH POL YMERASE CHAIN REACTION AMPLIFICATION

\section{W. L. McPheat* and Jane A. Bygraves}

Division of Bacteriology, National Institute of Biological Standard and Controls

Improved methods for confirming the diagnosis of $B$. pertussis infection are needed from both clinical and epidemiological points of view and in relation to monitoring vaccine efficacy. The definitive method of diagnosis is isolation of the organism from the nasopharynx of a patient. In practice, this is often unsuccessful because of poor viability or contamination of specimens. Most estimates indicate that culture is only successful in $c .30 \%$ of patients suffering from typical whooping cough symptoms, defined as a paroxysmal cough lasting more than 2 weeks associated with a typical whoop, vomiting, or apnoea, or any combination of these.

One approach to this problem is through the application of DNA probes for polynucleotide sequences that are unique to the organism. This would obviate the need for samples in which the bacteria were still viable and make diagnosis more rapid. An insertion sequence element IS.481 has been described by McPheat $e t$ al. $;^{30,31}$ it was 1053 bp in length and unique to the genus Bordetella. A 400-bp fragment of this sequence has been used as a probe to detect $B$. pertussis under experimental conditions and in clinical samples. Samples suspected to contain $B$. pertussis were subjected to the polymerase chain reaction (PCR) before hybridisation with the probe to enhance the sensitivity of diagnosis.

Samples were heated at $100^{\circ} \mathrm{C}$ for $10 \mathrm{~min}$ to release the target DNA from any $B$. pertussis cells present for amplification by PCR. They were then slot-blotted on to nylon filters to which the radio-labelled IS.481 fragment was hybridised. ${ }^{32}$ When the probe was hybridised directly to slot blots of $B$. pertussis cells, a minimum of approximately $5 \times$ $10^{5}$ cells were detected. The application of PCR to the $B$. pertussis cell suspensions enabled the detection of a minimum of about 100 cells, a 5000 -fold increase in the sensitivity of detection.

For preliminary evaluation of the probe, pernasal swabs from patients suspected of having pertussis were tested. The swabs were also cultured for $B$. pertussis. Of 38 swabs from patients with typical signs and symptoms of whooping cough but from which $B$. pertussis was not isolated, 13 gave positive results with the IS.481 probe after PCR amplification. Of these 38 patients, 26 had been vaccinated with DTP vaccine and 11 of these were included in the 13 positive reactors to the probe.

Of 13 culture-negative swabs from patients suffering from atypical whooping cough (a non-paroxysmal cough within 20 days of the onset of the primary case), two gave positive results with the probe after PCR amplification. Positive results were also obtained with four of eight swabs from patients from whom there was no information available.

These results indicated that use of the IS. 481 probe in conjunction with PCR amplification was effective in detecting $B$. pertussis DNA in samples from a substantial proportion of culture-negative patients with pertussis. As the yield of positive cultures from such patients is always low (rarely exceeding $30 \%$ of samples) because of the fragility of the organism and the difficulty of obtaining growth from samples with a low viable count, the use of this method of DNA detection, which does not depend upon viability or bacterial growth, should greatly increase the proportion of laboratory-confirmed diagnoses in this disease. This has important implications for vaccine trials, in which the precision of diagnosis may have a substantial influence on the apparent protective efficacy of a vaccine.

\section{IN SEARCH OF CENTRAL NER VOUS SYSTEM EFFECTS OF} PERTUSSIS VACCINE

\section{J. W. van der Laan}

Laboratory for Pharmacology, National Institute for Public Health and Environmental Protection, The Netherlands

Pertussis vaccination in children may be associated with serious side effects, such as convulsions, shock, persistent screaming and encephalopathy. The question arises whether 
the adverse convulsive effect of pertussis vaccination would be related to a direct or indirect effect on the central nervous system. A search for possible mechanisms of a convulsive effect has pursued the following lines:

(1) Influence on the latency of convulsions in mice induced by the classical convulsants pentylenetetrazole, thiosemicarbazide and 3-mercaptopropionic acid. No interaction was observed after treatment with pertussis vaccination ( $5 \mathrm{IU} / 100 \mathrm{~g}$ body weight).

(2) Influence on the $\gamma$-aminobutyric acid (GABA)-ergic system in brain, possibly in relation to cyclic guanosine monophosphate (cGMP). No consistent effects were found on the GABA-level in different parts of the brain, i.e., hippocampus, substantia nigra, cerebellum and cortex. Turnover of GABA was measured by use of the GABA-T inhibitor amino-oxyacetic acid. No change was found as a result of pertussis vaccination. The effects of pertussis vaccination on the cGMP level was studied in the areas mentioned above. The enhancement in the cerebellum found initially could not be reproduced in a second experiment. Because of this lack of reproducible effects it was concluded that pertussis vaccination had no effect on GABA and cGMP in rat brain.

(3) Influence on the level of signal transduction, i.e., the functional effects of stimulation of the $\alpha_{2}$-adrenoceptor. Pertussis vaccination did not affect either clonidineinduced sedation, or clonidine-induced hypothermia in adult animals. Also, when pertussis vaccine was given to newborn animals (on day 1, 4 or 7 after birth) no change was found in the behavioural effects of clonidine.

In conclusion, pertussis vaccination did not affect any of the mechanisms studied, which may be related to the convulsive threshold in animals.

\section{SUR VEILLANCE OF BORDETELLA PERTUSSIS SEROTYPES IN BRITAIN 1977-1989}

\section{S. Maxwell and N. W. Preston}

Pertussis Reference Laboratory, Division of Bacteriology, Department of Pathological Sciences, University of Manchester, Manchester M13 9PT

Serotypes of $B$. pertussis in various countries. Isolates of $B$. pertussis from many British hospitals and Public Health Laboratories, and from sources abroad, are serotyped at the Pertussis Reference Laboratory with antisera for AGGs 1, 2 and 3 . Three serotypes are prevalent $-1,2 ; 1,2,3 ; 1,3 ;$ a degraded serotype (type 1) is found in $<1 \%$ of cases. Changes in the predominant serotypes in various countries can be related to the efficacy of their vaccines. ${ }^{33}$

In non-vaccinated communities today, as in pre-vaccination years in Britain and elsewhere, highly fimbriate serotypes containing AGG 2 (i.e., serotypes 1,2 and 1,2,3) predominate. The early vaccines used in several countries contained AGG 1 and AGG 2 but rarely AGG3. This suppressed the prevalent strains, but led to a predominance of serotype 1,3 infections and a low vaccine efficacy (c. 20$25 \%$ in Britain in the 1960 s).

\section{References}

1. Redhead $\mathrm{K}$, Hill $\mathrm{T}$, Chart $\mathbf{H}$. Interaction of lactoferrin and transferrins with the outer membrane of Bordetella pertus. sis. J Gen Microbiol 1987; 133: 891-898.

2. Tamura M, Nogimori K, Murai S et al. Subunit structure of islet-activating protein, pertussis toxin, in conformity with the A-B model. Biochemistry 1982; 21: 5516-5522.

3. Witvliet MH, Burns DL, Brennan MJ, Poolman JT, Manclark CR. Binding of pertussis toxin to eucaryotic cells and glycoproteins. Infect Immun 1989; 57: 3324-3330.
Table IX. Changes in prevalence of $B$. pertussis serotypes in Britain, 1977-1987

\begin{tabular}{l|lcc}
\hline & \multicolumn{3}{c}{$\begin{array}{c}\text { Number of isolates serotyped (percentage } \\
\text { possessing AGG 2) from laboratories }\end{array}$} \\
$\begin{array}{c}\text { Epidemic } \\
\text { years }\end{array}$ & $\begin{array}{c}\text { throughout } \\
\text { Britain }\end{array}$ & in Swansea & in Chelmsford \\
\cline { 2 - 3 } $1977-1979$ & $4240(17)$ & $707(23)$ & $187(17)$ \\
$1981-1983$ & $3095(48)$ & $81(51)$ & $237(47)$ \\
$1985-1987$ & $2303(75)$ & $85(99)$ & $175(53)$ \\
\hline
\end{tabular}

In the 1970 s and early 1980 s, various countries experienced vaccines failure. Because children respond least well to AGG 3 in vaccines containing all three AGGs, serotype 1,3 became predominant in New Zealand which used an immunisation schedule of only two doses, and also in Canada which used three or more doses of plain vaccine (without adjuvant). Conversely, serotype 1,2 predominated in Finland which used serotype 1,3 vaccine, and in Australia which used a vaccine deficient in AGG 2 and AGG 3further evidence of the colonising advantage of serotype 1,2 .

Serotypes in recent epidemics of pertussis in Britain. The fall in infant vaccination-rate to a national average of $c .30 \%$ in the mid-1970s was followed by three epidemics. ${ }^{34}$ With the increasing proportion of non-vaccinated children, serotypes containing AGG 2 re-established themselves gradually as the predominant types (table IX). The change was most spectacular in Swansea where the vaccination rate fell as low as $9.5 \%$ in $1976 .{ }^{35}$ In contrast, these serotypes reached only approximate parity with serotype 1,3 in areas such as Chelmsford where the rate never fell as low as the national average.

A fourth epidemic has now begun, with c. 9000 notifications of clinical pertussis in the first 10 months of 1989 . Laboratories in England and Wales reported 609 isolates, of which 447 have been received by the Pertussis Reference Laboratory for serotyping. The proportion of serotype 1,3 isolates in Britain in $1989(33 \%)$ is increasing again, as the vaccination rate steadily improves.

Conclusion. There is a clear correlation between predominant serotype and vaccination rate. Strains containing AGG 2 are the best colonisers, and predominate when the rate is low; serotype 1,3 tends to re-emerge when vaccine containing all three AGGs is used, because the immune response to AGG 3 is the weakest. Thus, AGGs 2 and 3 are important factors in the pathogenesis of pertussis in man. Moreover, because deficiency in either AGG 2 or AGG 3 (in whole-cell vaccine) has been associated with subsequent infection in vaccinated children, it would not be sufficient for acellular vaccine to contain an unspecified AGG 2-3 component, or for sera of vaccinated children to react with this mixed component. The vaccine should contain AGG 2 and AGG 3 as separate components, and the sera of vaccinated children should be shown to react with each individually.

4. Sato $\mathbf{H}$, Ito $\mathrm{A}$, Chiba $\mathrm{J}$, Sato $\mathrm{Y}$. Monoclonal antibody against pertussis toxin: effect on toxin activity and pertussis infections. Infect Immun 1984; 46: 422-428.

5. Sato H, Sato Y, Ito A, Ohishi I. Effect of monoclonal antibody to pertussis toxin on toxin activity. Infect Immun 1987; 55: 909-915.

6. Sato H, Sato Y. Bordetella pertussis infection in mice : correlation of specific antibodies against two antigens, pertussis toxin, and filamentous hemagglutinin with mouse protectivity in an intracerebral or aerosol challenge system. Infect Immun $1984 ; 46$ : 415-421. 
7. Steinman L, Weiss A, Adelman $\mathrm{N}$ et al. Pertussis toxin is required for pertussis vaccine encephalopathy. Proc Natl Acad Sci USA 1985; 82: 8733-8736.

8. Nicosia A, Perugini M, Franzini Cet al. Cloning and sequencing of the pertussis toxin genes: operon structure and gene duplication. Proc Natl Acad Sci USA 1986; 83: 4631-4635.

9. Pizza M, Bartolini A, Prugnola A, Silvestri S, Rappuoli R. Subunit S1 of pertussis toxin: mapping of the regions essential for ADP-ribosyltransferase activity. Proc Natl Acad Sci USA 1988; 85: 7521-7525.

10. Pizza M, Covacci A, Bartolini A et al. Mutants of pertussis toxin suitable for vaccine development. Science $1989 ; 246$ : 497-500.

11. De Magistris MT, Romano M, Bartolini A, Rappuoli R, Tagliabue A. Human T cell clones define $S 1$ subunit as the most immunogenic moiety of pertussis toxin and determine its epitope map. $J$ Exp Med 1989 ; 169: 1519-1532.

12. Gray LS, Huber KS, Gray MC, Hewlett EL, Engelhard VH Pertussis toxin effects on $\mathrm{T}$ lymphocytes are mediated through CD3 and not by pertussis toxin catalyzed modification of a $G$ protein. J Immunol 1989; 142: 1631-1638.

13. Sekura RD, Zhang YL. Pertussis toxin: structural elements involved in the interaction with cells. In : Sekura RD, Moss J, Vaughan M (eds) Pertussis toxin. Orlando, Academic Press. 1985: 45-64.

14. Holt LB. The pathology and immunology of Bordetella pertussis infection. $J$ Med Microbiol 1972; 5: 407-424.

15. Sato Y, Izumiya K, Sato H, Cowell JL, Manclark CR. Role of antibody to leukocytosis-promoting factor hemagglutinin and to filamentous hemagglutinin in immunity to pertussis. Infect Immun 1981; 31: 1223-1231.

16. Gorringe AR, Ashworth LAE, Irons LI, Robinson A. Effect of monoclonal antibodies on the adherence of Bordetella pertussis to Vero cells. FEMS Microbiol Lett 1985; 26 : 5-9.

17. Brownlie RM, Coote JG, Parton R, Schultz JE, Rogel A, Hanski E. Cloning of the adenylate cyclase genetic determinant of Bordetella pertussis and its expression in Escherichia coli and B. pertussis. Microb Pathog 1988; 4: 335-344.

18. Rogel A, Farfel Z, Goldschmidt S, Shiloach J, Hanski E. Bordetella pertussis adenylate cyclase. Identification of multiple forms of the enzyme by antibodies. $J$ Biol Chem $1988 ; 263: 13310-13316$

19. Rogel A, Schultz JE, Brownlie RM, Coote JG, Parton R, Hanski E. Bordetella pertussis adenylate cyclase: purification and characterization of the toxic form of the enzyme. $E M B O J 1989 ; 8$ : 2755-2760.
20. Cookson BT, Tyler AN, Goldman E. Primary structure of the peptidoglycan-derived tracheal cytotoxin of Bordetella pertussis. Biochemistry 1989; 28 : 1744-1749.

21. Goldman WE, Klapper DG, Baseman JB. Detection, isolation, and analysis of a released Bordetella pertussis product toxic to cultured tracheal cells. Infect Immun 1982; 36: 782-794.

22. Goldman WE, Herwaldt LA. Bordetella pertussis tracheal cytotoxin. Dev Biol Stand 1985; 61 : 103-111.

23. Goldman WE, Cookson BT. Structure and functions of the Bordetella tracheal cytotoxin. Tokai J Exp Clin Med 1988; 13 Suppl: 187-191.

24. Folkening WJ, Nogami W, Martin SA, Rosenthal RS. Structure of Bordetella pertussis peptidoglycan. J Bacteriol 1987; 169 : 4223-4227.

25. Novotny P, Chubb AP, Cownley K, Montaraz JA, Beesley JE. Bordetella adenylate cyclase: a genus specific protective antigen and virulence factor. Dev Biol Stand 1985; 61 : 27 41.

26. Munoz JJ, Peacock MG. Role of pertussigen (pertussis toxin) on the mouse protective activity of vaccines made from Bordetella species. Microbiol Immunol 1989; 33: 341-355.

27. Svoboda M, Hannecart-Pokorni E, Borremans M, Christophe J. Rapid purification of Bordetella pertussis toxin by alternating affinity and hydrophobic chromatography. Anal Biochem 1986; 159: 402-411.

28. Bartolini A, Pizza M, Gross R et al. Engineering bacterial toxin for the development of new vaccine against pertussis. Tokai J Exp Clin Med 1988; 13 Suppl: 217-222.

29. Mussett MV, Sheffield F. A collaborative investigation of methods proposed for the potency assay of adsorbed diphtheria and tetanus toxoids in the European Pharmacopoeia. J Biol Stand 1973; 1: 259-283.

30. McPheat WL, McNally $T$. Isolation of a repeated DNA sequence from Bordetella pertussis. J Gen Microbiol 1987; 133: 323-330.

31. McPheat WL, Hanson JH, Livey I, Robertson JS. Analysis of separate isolates of Bordetella pertussis repeated DNA sequences. J Gen Microbiol 1989; 135 : 1515-1520.

32. Tenover FC. Diagnostic deoxyribonucleic acid probes for infectious diseases. Clin Microbiol Rev 1988; 1 : 82-101.

33. Preston NW. Pertussis today. In: Wardlaw AC, Parton R (eds) Pathogenesis and immunity in pertussis. Chichester, John Wiley. 1988: 1-18

34. Maxwell S, Preston NW. Surveillance of pertussis in Britain: 1985-88. Communicable Disease Report 89/34. London, Public Health Laboratory Service. 1989: 3-4.

35. Swansea Research Unit, Royal College of General Practitioners. Effect of low pertussis vaccination uptake on a large community. Br Med J 1981; 282: 23-26. 